\title{
On the gas-ice depth difference ( $\Delta$ depth) along the EPICA Dome C ice core
}

\author{
F. Parrenin ${ }^{1,2}$, S. Barker ${ }^{3}$, T. Blunier ${ }^{4}$, J. Chappellaz ${ }^{2}$, J. Jouzel ${ }^{5}$, A. Landais ${ }^{5}$, V. Masson-Delmotte ${ }^{5}$, J. Schwander ${ }^{6}$, \\ and D. Veres ${ }^{2,7}$ \\ ${ }^{1}$ Laboratoire Chrono-Environnement, Besançon, France \\ ${ }^{2}$ UJF Grenoble 1, UMR5183, CNRS - Laboratoire de Glaciologie et Géophysique de l'Environnement (LGGE), \\ Grenoble 38041, France \\ ${ }^{3}$ School of Earth and Ocean Sciences, Cardiff University, UK \\ ${ }^{4}$ Centre for Ice and Climate, Niels Bohr Institute, University of Copenhagen, Copenhagen, Denmark \\ ${ }^{5}$ Laboratoire des Sciences du Climat et de l'Environnement, Gif-sur-Yvette, France \\ ${ }^{6}$ Physics Institute, University of Bern, Bern, Switzerland \\ ${ }^{7}$ Institute of Speleology, Romanian Academy, Cluj-Napoca, Romania
}

Correspondence to: F. Parrenin (parrenin@ujf-grenoble.fr)

Received: 13 March 2012 - Published in Clim. Past Discuss.: 3 April 2012

Revised: 5 July 2012 - Accepted: 5 July 2012 - Published: 2 August 2012

\begin{abstract}
We compare a variety of methods for estimating the gas/ice depth offset ( $\Delta$ depth) at EPICA Dome $\mathrm{C}$ (EDC, East Antarctica). (1) Purely based on modelling efforts, $\Delta$ depth can be estimated combining a firn densification with an ice flow model. (2) The diffusive column height can be estimated from $\delta^{15} \mathrm{~N}$ and converted to $\Delta$ depth using an ice flow model and assumptions about past average firn density and thickness of the convective zone. (3) Ice and gas synchronisation of the EDC ice core to the GRIP, EDML and TALDICE ice cores shifts the ice/gas offset problem into higher accumulation ice cores where it can be more accurately evaluated. (4) Finally, the bipolar seesaw hypothesis allows us to synchronise the ice isotopic record with the gas $\mathrm{CH}_{4}$ record, the later being taken as a proxy of Greenland temperature. The general agreement of method 4 with methods 2 and 3 confirms that the bipolar seesaw antiphase happened during the last $140 \mathrm{kyr}$. Applying method 4 to the deeper section of the EDC core confirms that the ice flow is complex and can help to improve our reconstruction of the thinning function and thus, of the EDC age scale. We confirm that method 1 overestimates the glacial $\Delta$ depth at EDC and we suggest that it is due to an overestimation of the glacial lock-in depth (LID) by the firn densification model. In contrast, we find that method 1 very likely underestimates $\Delta$ depth during Termination II, due either to
\end{abstract}

an underestimated thinning function or to an underestimated LID. Finally, method 2 gives estimates within a few metres of methods 3 and 4 during the last deglacial warming, suggesting that the convective zone at Dome $\mathrm{C}$ cannot have been very large at this time, if it existed at all.

\section{Introduction}

Ice cores provide a wealth of information on past climatic variations (Jouzel et al., 2007; Pol et al., 2011) and on past greenhouse gases concentrations (Lüthi et al., 2008; Loulergue et al., 2008) at time scales ranging from centennial to orbital (Earth orbit variations, $10^{4}-10^{5} \mathrm{yr}$ ).

To interpret the records from ice cores, it is essential to derive accurate chronologies (e.g., Parrenin et al., 2007b). One of the peculiarities of ice core dating is that two age scales need to be derived: one for the ice matrix and one for the gas phase. Gas bubbles are always younger than the surrounding ice because they close off and trap the air at $50-120 \mathrm{~m}$ (depending on site conditions) below the surface, after the snow has densified into ice (Schwander and Stauffer, 1984). What is important for paleoclimatic studies is the lock-in depth (LID) where gas diffusion becomes negligible, and which is slightly smaller than the close-off depth (COD) where it is 
not possible to pump air (Witrant et al., 2011). The determination of this ice/gas offset is essential, however, to derive the phase relationship between proxies recorded in the ice phase and in the gas bubbles. As an example, $\mathrm{CO}_{2}$ was estimated to lag Antarctic temperature changes by $800 \pm 600 \mathrm{yr}$ during the last deglaciation (Monnin et al., 2001) by $800 \pm 200 \mathrm{yr}$ during Termination III (Caillon et al., 2003), and on average by $600 \pm 400 \mathrm{yr}$ during the last three deglaciations (Fischer et al., 1999). This finding suggests that $\mathrm{CO}_{2}$ was an amplifier rather than the initial trigger of glacial terminations, although this view has been challenged by more recent studies (Loulergue et al., 2007; Pedro et al., 2012).

The gas/ice offset can be characterized in two different ways. $\Delta$ age measures the difference in age between the ice and gas phases at any given depth. $\Delta$ depth, on the other hand, represents the depth difference between gas and ice of the same age. Each parameter has advantages and drawbacks. $\Delta$ age is fixed when the gas is locked in and does not evolve with time because there is no relative movement of the gas bubbles or hydrates with respect to the surrounding ice. $\Delta$ age is, however, strongly dependent on the rate of surface snow accumulation at the site, which is poorly constrained for the past; for a given LID and a given density profile, $\Delta$ age is inversely proportional to the accumulation rate. By contrast, $\Delta$ depth is independent of the reference age scale used. It is only weakly dependent on accumulation rate since both the LID and the thinning function are only weakly affected by changes in accumulation rate. However, it continually evolves as the ice thins, which complicates its evaluation. Inversely, having observations of $\Delta$ depth from ice and gas proxies can provide useful information on the past flow of ice. Moreover, an error on $\Delta$ depth (expressed in metres) should be converted into years (using a prior chronology) to give an uncertainty on the ice-gas phasing (e.g. $\mathrm{CO}_{2}$ /temperature).

In this paper we focus on the evaluation of the $\Delta$ depth along the EDC (EPICA Dome C) ice core using different approaches. They fall into two broad categories: (1) estimation of the initial LID of gas bubbles and estimation of the thinning of snow/ice layers; and (2) determination of synchronous events in gas and ice proxy records. The results will be inter-compared and discussed.

Note that in the following, we have to deal with datasets on both the EDC96 and EDC99 ice cores. We systematically transfer all EDC96 datasets to EDC99 depths using a linear interpolation of the volcanic tie points between both cores (Parrenin et al., 2012). We use the same depth-depth relationship for both gas and ice datasets, i.e. we assume that $\Delta$ age as a function of age is the same for both cores.

\section{Methods}

\section{1 $\Delta$ depth from ice flow and densification models}

From a mechanical point of view, $\Delta$ depth is given by:

$$
\int_{0}^{h} \frac{D\left(z^{\prime}, t\right)}{\tau\left(z^{\prime}, t\right)} \mathrm{d} z^{\prime}=\int_{z-\Delta \operatorname{depth}(z)}^{z} \frac{D\left(z^{\prime}, t=0\right)}{\tau\left(z^{\prime}, t=0\right)} \mathrm{d} z^{\prime},
$$

where $D\left(z^{\prime}\right)$ and $\tau\left(z^{\prime}\right)$ are respectively the density of the material relative to pure ice and the thinning as a function (the ratio of a layer thickness to its initial thickness) of the depth $z^{\prime}$ and $h$ is the lock-in depth (LID) at the time $t$ when the initial snow layer, which is now ice at depth $z-\Delta$ depth $(z)$, was at surface. We further define $h_{\text {ie }}$ the lock-in depth in ice equivalent (LIDIE):

$h_{\text {ie }}=\int D(y, t) \mathrm{d} y$,

Using this formalism, $\Delta$ depth is a function of the gas depth. We implicitly assumed that at a given depth $z$, the gas age is uniquely defined. In reality, because of gas diffusion in the firn and because of the gradual bubble close off process, any depth contains a distribution of age which can be accurately approximated by a log-normal function (Köhler, 2010). We implicitly use here the median of this log-normal distribution as the so-called gas age for any given depth.

$D\left(z^{\prime}, t=0\right)$ can be estimated by measuring the weight and the volume of the drilled cores. However, no reliable quantitative proxy has been proposed for $\tau\left(z^{\prime}, t=0\right), \tau\left(z^{\prime}, t\right)$ and $D\left(z^{\prime}, t\right)$ and their evaluation usually relies on ice flow (e.g., Reeh, 1989; Parrenin et al., 2007a; Salamatin et al., 2009b) and firn densification modelling (e.g., Herron and Langway, 1980; Arnaud et al., 2000; Salamatin et al., 2009a). We will detail in the following the ice flow model and firn densification model used in this study.

\subsubsection{Ice flow model}

A one-dimensional (1-D) ice flow model has been used to construct the modelled age scale $\chi_{\mathrm{m}}$ at the EDC drilling site and to derive a modelled thinning function $\tau_{\mathrm{m}}$ (Parrenin et al., 2007a). In this model, the vertical velocity $u_{\bar{z}}$ of the ice relative to the bedrock is expressed as:

$u_{\bar{z}}(\bar{z})=-\left[m+\left(a-\frac{\partial H}{\partial t}-m\right) \omega(\zeta)\right]$

where $z$ is the vertical coordinate of the ice particle (oriented toward the top), $\bar{z}=z-B$ is the distance to the bedrock ( $B$ is the bedrock elevation), $\zeta=\bar{z} / H$ is the non-dimensional vertical coordinate, $m$ is the melting rate at the base of the ice sheet, $a$ is the surface accumulation rate, $H$ is the ice thickness and $\frac{\partial H}{\partial t}$ is its temporal variation. $\omega(\zeta)$, called the flux shape function (Parrenin and Hindmarsh, 2007), depends on 
the non-dimensional vertical coordinate and is the contribution of one sliding term and one deformation term:

$\omega(\zeta)=s \zeta+(1-s) \omega_{D}(\zeta)$

where $s$ is the sliding ratio (ratio of the basal horizontal velocity to the vertically averaged horizontal velocity; it is 0 for no sliding and 1 for full sliding) and $\omega_{D}(\zeta)$ can be approximated by (Lliboutry, 1979):

$\omega_{D}(\zeta)=1-\frac{p+2}{p+1}(1-\zeta)+\frac{1}{p+1}(1-\zeta)^{p+2}$

where $p$ is a parameter for the vertical profile of deformation $\omega_{D}(\zeta)$. The values of $p, m$ and $s$ are assumed constant through time.

The past variations of ice thickness $H(t)$ are obtained from a 1-D model (Parrenin et al., 2007a) fitted onto the results of a 3-D model of the Antarctic ice sheet (Ritz et al., 2001). The main process is the reduced accumulation rate during glacial times, which induces a lower elevation (and reduced ice thickness) at Dome C during glacial periods. However, preliminary results with an improved 3-D model with increased spatial resolution suggests that the presence of an ice sheet in the Ross Embayment might limit the impact of a reduced accumulation on the elevation at the EDC site, at least during the last glacial maximum (C. Ritz, personal communication, 2012). This is why, in the following, we will also test the hypothesis of zero ice thickness variations at the EDC site. This appears as an extreme case, given that some geomorphological data in the Transantarctic Mountains show little elevation change of the Antarctic plateau for the last glacial maximum (Denton et al., 1989), despite the presence of the ice sheet in the Ross Embayment.

Modelled accumulation $a_{\mathrm{m}}$ and temperature $T$ are deduced from the deuterium content of the ice extracted from the drill core, through the following relationships:

$a_{\mathrm{m}}=a^{0} \exp \left(\beta \Delta \delta D_{\text {smo }}\right)$

$T=T^{0}+\alpha \Delta \delta D_{\text {cor }}$

where $a^{0}$ and $T^{0}$ are surface accumulation and temperature for a reference deuterium content of $-396.5 \%$ (roughly corresponding to the present-day value). $\Delta \delta D_{\text {smo }}$ is a $50-\mathrm{yr}$ smoothed version of $\Delta \delta D_{\text {cor }}$ because the accumulation rate $a_{\mathrm{m}}$ is supposed to be related to the isotope content of the deposited snow only over a certain time interval (high frequency variations of deuterium may be affected by post depositional processes such as wind scouring). The poorly constrained glaciological parameters $p=2.30, m=0.066 \mathrm{~cm}$ of-ice $\mathrm{yr}^{-1}, s=2.23 \%, a^{0}=2.841 \mathrm{~cm}$-of-ice $\mathrm{yr}^{-1}$ and $\beta=$ 0.0157 were obtained by fitting independent age markers identified within the core (Parrenin et al., 2007a). The inferred value for $\beta$ appears consistent with modern spatial gradients in central East Antarctica (Masson-Delmotte et al.,
2008). Given the inability of the model to fit some age markers (Dreyfus et al., 2007; Parrenin et al., 2007b), the thinning function $\tau$ and surface accumulation rate $a$ were tuned a posteriori using a spline method so that the tuned age scale $\chi$ fit these age markers (see Appendices of Parrenin et al., 2007b; Dreyfus et al., 2007).

It is difficult to quantify the uncertainty on the modelled thinning function $\tau_{\mathrm{m}}(z)$ because we do not know which processes are not accounted for in the ice flow models. Here we consider only the non-laminar ice flow effects and assume that the error they induce on $\ln \left(\tau_{\mathrm{m}}\right)$ is:

$\sigma_{\ln }(\tau)(z)=\frac{k}{H} \int \frac{D\left(z^{\prime}\right)}{\tau_{\mathrm{m}}\left(z^{\prime}\right)} \mathrm{d} z^{\prime}$,

where $D(z)$ is the density of the material relative to pure ice and $k$ is a proportionality coefficient. We infer the value of $k$ with a residual approach using the multiplicative correction for the thinning function $C(z)$ which has been inferred from the orbital tuning of $\delta^{18} \mathrm{O}_{\mathrm{atm}}$ in the 2700-3200 $\mathrm{m}$ interval of the EDC ice core (Dreyfus et al., 2007). $k$ is simply given by the standard deviation of the following function $f(z)$ :

$f(z)=\ln (C(z))\left(\frac{1}{H} \int \frac{D(z)}{\tau_{\mathrm{m}}\left(z^{\prime}\right)} \mathrm{d} z^{\prime}\right)^{-1}$,

which is represented in Fig. 1. This gives $k=0.0974$ and the resulting $\sigma_{\ln (\tau)}$ function is plotted in Fig. 2.

\subsubsection{Firn densification model}

For the firn densification modelling exercise and the determination of $D(z)$, we used the Arnaud/Goujon model (Goujon et al., 2003). Arnaud et al. (2000) developed an advanced densification model which considers two densification stages: pure sliding of snow grains for density lower than $\sim 0.55 \mathrm{~g} \mathrm{~cm}^{-3}$, and pure deformation of grains for density higher than $\sim 0.55 \mathrm{~g} \mathrm{~m}^{-3}$. Goujon et al. (2003) then incorporated heat transfer into this model. In the applications below we used a surface density of $0.35 \mathrm{~g} \mathrm{~cm}^{-3}$.

The lock-in density $D(z=h)$ is determined from the total air content (TAC) of the ice (Martinerie et al., 1992, 1994; Raynaud et al., 2007) corrected for local atmospheric pressure changes (due in particular to elevation changes) using the perfect gas law. In the applications below, for simplification and based on the approach by Martinerie et al. (1992, 1994), we use a conventional linear empirical relationship between the volume of pores at close-off $\left(V_{\mathrm{c}}, \mathrm{cm}^{3} \mathrm{~g}^{-1}\right)$ and surface temperature $T_{\mathrm{S}}(\mathrm{K})$ as:

$V_{\mathrm{c}}=6.95 \times 10^{-4} T_{\mathrm{S}}-0.043$

The evolution of closed porosity in the firn, $P_{\text {closed }}$, is deduced from the following relationship:

$P_{\text {closed }}=0.37 P_{\text {total }}\left(\frac{P_{\text {total }}}{P_{\text {close-off }}}\right)^{-7.6}$, 


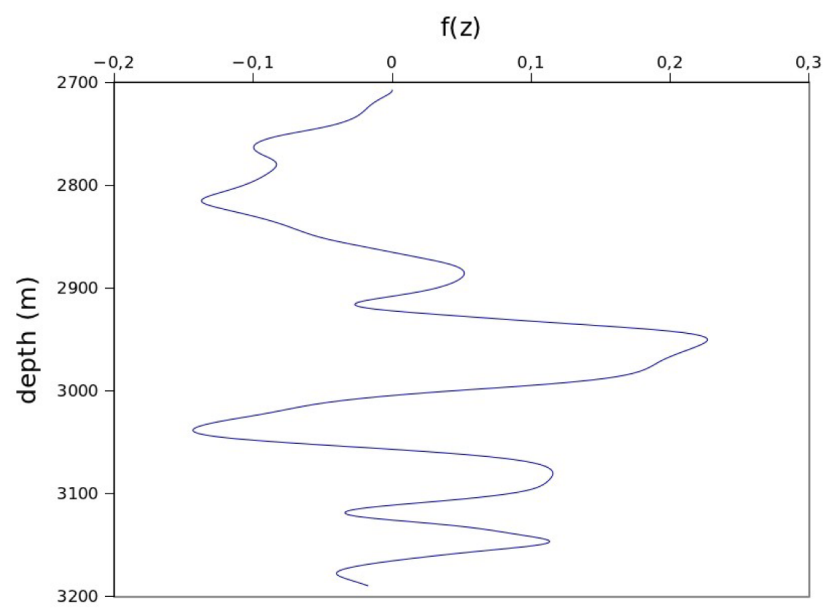

Fig. 1. Function $f(z)$ in EDC as described in Eq. (9).

which has been calibrated with $P_{\text {closed }}$ and $P_{\text {total }}$ measurements on several ice cores from Greenland and Antarctica (J.-M. Barnola, personal communication, 2009). This relationship means that at close-off, $37 \%$ of the pores are closed. The LID is further defined, at EDC, when $20 \%$ of the pores are closed.

The steady LID, $\Delta$ age and LIDIE/LID ratio simulated by the Goujon/Arnaud model are represented in Fig. 3 in a surface temperature-surface accumulation diagram for a surface density of $0.35 \mathrm{~g} \mathrm{~cm}^{-3}$. Qualitatively speaking, LID is greater for a greater accumulation or for a lower temperature, whereas $\Delta$ age is greater for a lower accumulation or for a lower temperature. The LIDIE/LID ratio is practically constant: it only varies between 0.682 and 0.702 for the accumulation and temperature ranges considered in Fig. 3.

\section{$2.2 \Delta$ depth from ice flow modelling and $\delta^{15} \mathrm{~N}$-based estimates of firn thickness}

The ice flow modelling part of this estimate has been described above. We use here the variations of ice thickness at EDC as derived for the EDC3 age scale (Parrenin et al., 2007a, b).

Now $h$ is estimated using the fact that, below a convective zone of height $h_{\text {conv }}$ where the air is mixed (Colbeck, 1989, 1997; Sowers et al., 1992; Bender et al., 1994; Kawamura et al., 2006), gravitational settling enriches heavy isotopes of inert gases (such as $\delta^{15} \mathrm{~N}$ of $\mathrm{N}_{2}$ and $\delta^{40} \mathrm{Ar}$ ) proportionally to the diffusive column height $h_{\text {diff }}$ (Craig et al., 1988; Sowers et al., 1989; Dreyfus et al., 2010) until gases no longer diffuse in the open pores. We implicitly assume here that all gases stop diffusing at the same depth. Note that a recent study suggested that some trace gases continue to diffuse below the LID defined by the start of the $\delta^{15} \mathrm{~N}$ plateau (Buizert et al., 2012). In delta notation, this gravitational fractionation is expressed as:

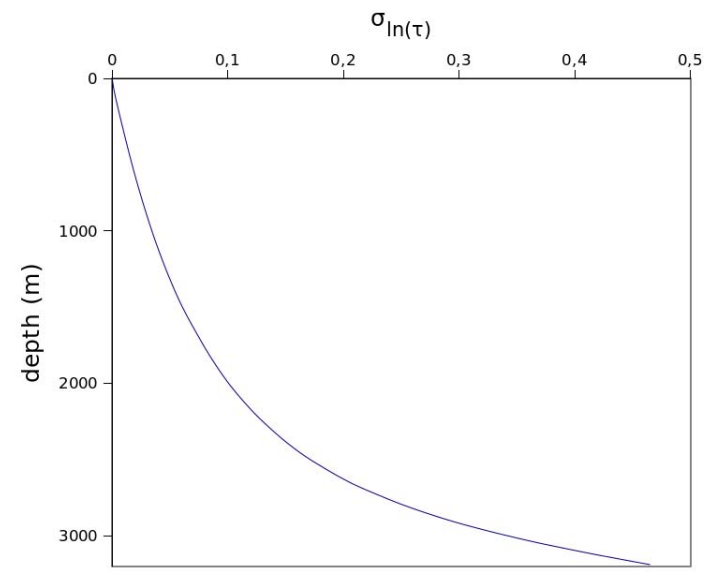

Fig. 2. Evolution of the error in the logarithm of thinning function as a function of the depth in the EDC ice core.

$\delta_{\text {grav }}=\left[\exp \left(\frac{\Delta m g h_{\text {diff }}}{R T}\right)-1\right] \times 1000$,

where $\Delta m$ is the mass difference between species $\left(\mathrm{kg} \mathrm{mol}^{-1}\right), g$ is the gravitational acceleration $\left(9.825 \mathrm{~m} \mathrm{~s}^{-2}\right.$ for Antarctica), $R$ is the universal gas constant $\left(8.314 \mathrm{~J} \mathrm{~mol}^{-1} \mathrm{~K}^{-1}\right.$ ) and $T$ is the firn temperature $(\mathrm{K})$. Equation (12) can be approximated within $0.02 \%$ with:

$\delta_{\text {grav }} \simeq\left(\frac{\Delta m g h_{\text {diff }}}{R T}\right) \times 1000$.

Thermal fractionation of $\delta^{15} \mathrm{~N}$ occurs because of the temperature difference $\Delta T$ between the surface and the LID:

$\delta_{\mathrm{th}}=\Omega(T) \Delta T_{\text {diff }}$,

where $\Delta T_{\text {diff }}$ is the temperature difference between the top and the bottom of the diffusive zone. $\Omega(T)$ has been estimated from laboratory measurements (Grachev and Severinghaus, 2003).

Conversely, one can deduce $h$ from the $\delta^{15} \mathrm{~N}$ data at EDC, measured on the last three glacial terminations and five glacial-interglacial cycles between 300 and $800 \mathrm{kyr} \mathrm{BP}$ (Dreyfus et al., 2010):

$h=h_{\mathrm{conv}}+\left(\delta^{15} \mathrm{~N}-\Omega(T) \Delta T_{\text {diff }}\right)\left(\frac{\Delta m g \times 1000}{R T}\right)^{-1}$.

One of the reasons for variations in the convective height is the change of wind stress. GCM experiments for the LGM show little variations in wind on the East Antarctic plateau (Krinner et al., 2000). Note that we have evidence for a large convective zone at present at some sites (Bender et al., 2006; Severinghaus et al., 2010). In the applications below, we will assume that there was no convective zone at EDC during the last $800 \mathrm{kyr}$, in agreement with current observations (Landais 

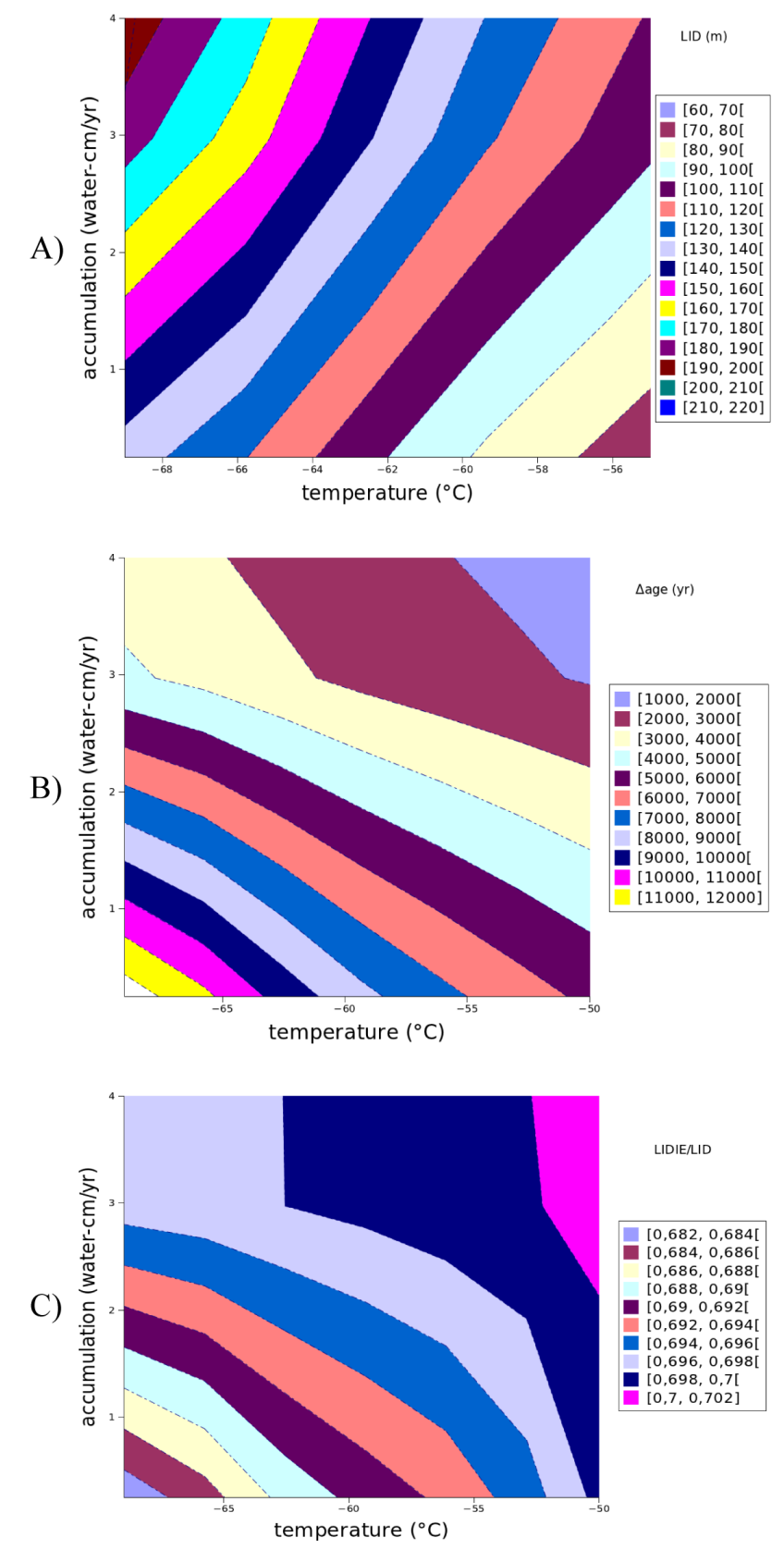

Fig. 3. Simulations of the Goujon/Arnaud firn densification model (Goujon et al., 2003), in a (surface temperature-surface accumulation) diagram. Surface density is $0.35 \mathrm{~g} \mathrm{~cm}^{-3}$. LID is taken at $20 \%$ of closed porosity. (A) Simulated LID; (B) Simulated $\Delta$ age; (C) Simulated LIDIE/LID ratio.

et al., 2006). We will be able to assess the limits of our assumption about the convective zone when we compare the results from the different methods. We further deduce the temperature difference in the firn $\Delta T_{\text {diff }}$ from simulations of the temperature field by the Goujon/Arnaud model (Loulergue et al., 2007, scenario 1). We take the surface temperature as computed for the EDC3 age scale (Parrenin et al., 2007a), as a function of the ice depth. We also need a prior $\Delta$ depth estimate to convert the ice depths to gas depths and we use the EDC3 scenario 1 estimate (Loulergue et al., 2007). We estimate the uncertainty on the temperature estimate to be $<4 \mathrm{~K}$ which translates into a $<2 \% 2 \sigma$ error on $h$. We also estimate the uncertainty on the temperature gradient to be $<0.003 \mathrm{~K} \mathrm{~m}^{-1}$ which translates into a $<1 \% 2 \sigma$ error on $h$.

Following the Goujon/Arnaud model simulations (see Fig. 3c), Eq. (2) is simplified into:

$h_{\text {ie }} \simeq h \times 0.698$.

Bender et al. (2006) also used a similar approximation. It corresponds to assuming that the average density of the firn is correctly predicted by the Goujon/Arnaud model. If this model would not predict the right average densification velocity but would predict instead the right densification profile shape, this approximation would still be valid. So this leaves us with mainly two reasons why this approximation would not be valid: (1) a variable surface density and/or (2) a variable lock-in density. Option (1) cannot be ruled out since, depending on the characteristics of the surface (glazed surface, megadunes, etc.), surface densities $>0.4 \mathrm{~g} \mathrm{~cm}^{-3}$ are observed on the East Antarctic plateau (Courville et al., 2007). Note that because the densification velocity is greater at surface than in depth, an error of $x$ on the surface density has a relatively low impact of $\sim x / 3$ on the average density. Because the density at the COD does not change very much with time (it is well constrained by the measured total air content of the ice), option (2) would imply a varying difference between LID and COD. In total, we estimate the $2 \sigma$ error of Eq. (16) to be $5 \%$. Equation (1) is solved assuming the thinning function expressed as a function of $z_{\mathrm{ie}}$, the ice equivalent depth, was the same at the time of deposition as for the present. The error of this approximation is due to the varying basal melting/accumulation ratio and to the varying ice thickness (Parrenin et al., 2007a), but we evaluate it to be $<0.1 \%$ on $\Delta$ depth.

\section{3 $\Delta$ depth from ice and gas synchronisation to GRIP}

$\Delta$ depth at the depth of the ${ }^{10}$ Be peak (Raisbeck et al., 2007) in the EDC ice core can be estimated by linking the ice and gas signals to GRIP (Loulergue et al., 2007). The ice link is obtained by ${ }^{10} \mathrm{Be}$ synchronisation of EDC and GRIP for two ${ }^{10} \mathrm{Be}$ sub-peaks corresponding to the Laschamp geomagnetic event (Raisbeck et al., 2007). The gas link is obtained by matching the EDC $\mathrm{CH}_{4}$ record to the GRIP ice isotopic record (Fig. 4), assuming that these two records are synchronous during the rapid Dansgaard-Oeschger (DO) transitions (Flückiger et al., 2004; Huber et al., 2006). In Fig. 4, we align the onsets of DO9 and DO11 and remark that the onset of DO10 is also aligned. Linear interpolations allow obtaining the corresponding gas depths in EDC99. Our horizontal scale is expressed in GRIP ages, since there are significant variations of accumulation which would make the 


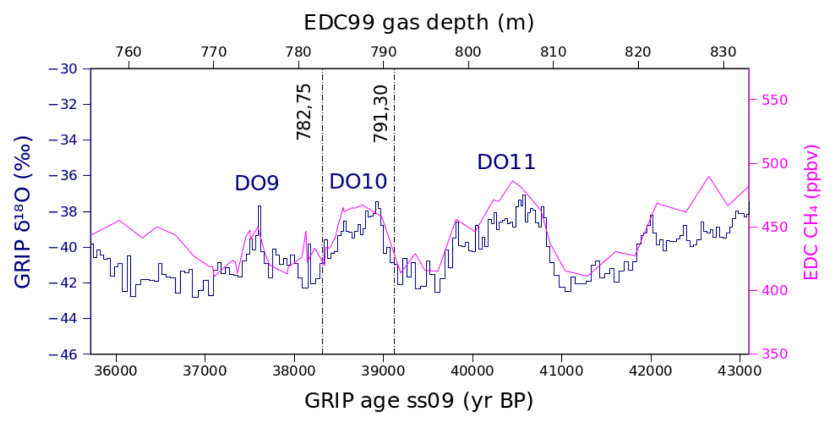

Fig. 4. Synchronisation of GRIP $\delta^{18} \mathrm{O}$ and $\mathrm{EDC} \mathrm{CH}_{4}$ during DO911. The two vertical dashed lines mark the position of the ${ }^{10} \mathrm{Be}$ sub-peaks in the GRIP core and give the corresponding gas depths in the EDC99 ice core.

interpolation inaccurate in depths. It is not necessary to use an age scale for EDC since the variations of accumulation are small and the variations of thinning are $<2 \%$ over the considered interval.

This finally gives these two estimates of the $\Delta$ depth at EDC99: $\Delta$ depth at $782.9 \mathrm{~m}=48.9 \pm 2 \mathrm{~m}(2 \sigma)$; and $\Delta$ depth at $791.5 \mathrm{~m}=48.2 \pm 2 \mathrm{~m}(2 \sigma)$. The uncertainty accounts for the uncertainty in the ${ }^{10} \mathrm{Be}$ sub-peaks positions in $\operatorname{EDC}(1.1 \mathrm{~m})$ and in GRIP (1.1 m EDC equivalent depth) and for the GRIPEDC synchronisation $(1.3 \mathrm{~m})$.

\section{4 $\Delta$ depth from ice and gas synchronisation to EDML}

Another approach to deduce EDC $\Delta$ depth is to synchronise the ice core records, both in the ice and gas phases, to a higher accumulation Antarctic ice core, such as EDML (see Fig. 5) which has a better constrained ice/gas offset (Loulergue et al., 2007). Such an approach has already been applied to constrain the Vostok gas/ice offset using data from the Byrd ice core record (Blunier et al., 2004; Bender et al., 2006) and the EDC gas/ice offset using EDML (Loulergue et al., 2007). The EDC and EDML ice cores have been synchronised (Severi et al., 2007; Ruth et al., 2007) using volcanic stratigraphic markers recorded in the ice phase. Here we also derive 20 new $\mathrm{CH}_{4}$ tie points (see Table 1 and Fig. 6) (Loulergue et al., 2007, 2008; Schilt et al., 2010), mainly at the onsets of Greenland Interstadials (GI) over the period 0-140 kyr BP. We did not use systematically the tie points of Loulergue et al. (2007) or of Schilt et al. (2010) since (1) we do not use ends of GIs because they are less well marked than the onsets and therefore bring little information with respect to the neighbouring onsets, (2) we do not use GI2 and GI9 because we reckon their identification is too ambiguous, and (3) we choose the tie points exactly at the mid-transitions. The evaluation of $\Delta$ depth at EDC now relies on its evaluation at EDML. We derived the latter from Eq. (1). For the thinning, we did not use estimates based on an ice flow model (Huybrechts et al., 2007) because for the same age, the depth is larger at EDML than at EDC and the evaluation of the
Table 1. $\mathrm{CH}_{4}$ synchronisation tie points between EDC and EDML and corresponding $\Delta$ depth estimates at EDC.

\begin{tabular}{lrrrr}
\hline Description & $\begin{array}{r}\text { EDC99 gas } \\
\text { depth }(\mathrm{m})\end{array}$ & $\begin{array}{r}\text { EDML gas } \\
\text { depth }(\mathrm{m})\end{array}$ & $\begin{array}{r}\Delta \text { depth } \\
(\mathrm{m})\end{array}$ & $\begin{array}{r}1 \sigma \text { uncertainty } \\
(\mathrm{m})\end{array}$ \\
\hline YD-Hol & 418.5 & 718.0 & 58.4 & 3.84 \\
BA-YD & 443.5 & 766.4 & 56.2 & 3.79 \\
onset BA & 476.1 & 830.2 & 55.4 & 3.92 \\
onset DO3 & 639.1 & 1155.1 & 49.7 & 3.32 \\
onset DO4 & 651.9 & 1174.2 & 50.2 & 3.37 \\
onset DO5 & 688.1 & 1233.7 & 49.3 & 3.26 \\
onset DO6 & 702.1 & 1260.8 & 46.3 & 3.05 \\
onset DO7 & 719.7 & 1286.4 & 48.3 & 3.15 \\
onset DO8 & 751.3 & 1338.0 & 47.9 & 3.23 \\
onset DO10 & 791.0 & 1404.6 & 48.0 & 3.10 \\
onset DO11 & 809.2 & 1439.0 & 42.0 & 3.32 \\
onset DO12 & 848.5 & 1490.0 & 44.0 & 3.09 \\
onset DO14 & 925.0 & 1601.8 & 43.6 & 2.99 \\
onset DO17 & 986.5 & 1688.2 & 43.0 & 2.92 \\
onset DO18 & 1038.5 & 1760.5 & 43.1 & 2.82 \\
onset DO19 & 1105.0 & 1861.3 & 41.2 & 3.05 \\
onset DO20 & 1142.0 & 1915.0 & 39.4 & 2.73 \\
onset DO21 & 1239.0 & 2023.2 & 34.2 & 3.01 \\
onset DO24 & 1473.0 & 2230.3 & 28.3 & 2.32 \\
onset MIS5.5 & 1722.0 & 2369.0 & 38.2 & 3.18 \\
\hline
\end{tabular}

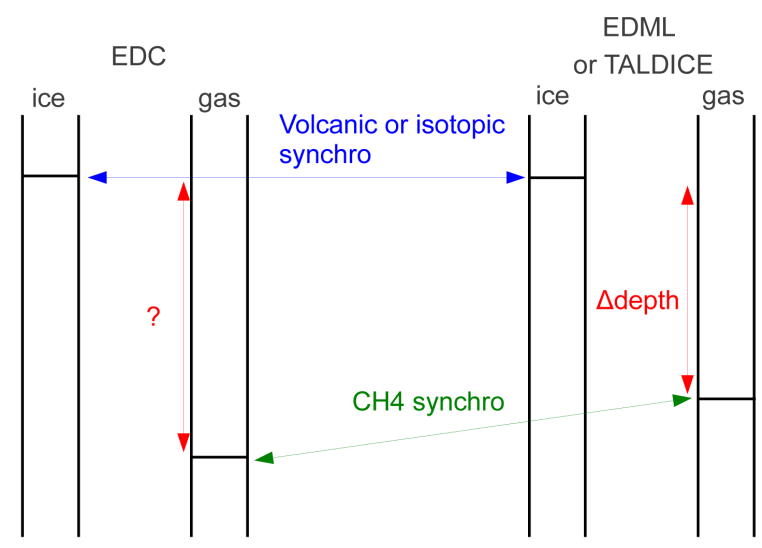

Fig. 5. Scheme illustrating the deduction of the $\Delta$ depth at EDC from ice (volcanic) and gas $\left(\mathrm{CH}_{4}\right)$ synchronisation to the EDML or TADLICE ice cores and evaluation of $\triangle$ depth at EDML or TALDICE.

thinning function from ice flow modelling thus becomes inaccurate. Instead, we fixed the EDML1 age scale (synchronised to EDC3, Ruth et al., 2007), used EDML accumulation rates from Loulergue et al. (2007, scenario 1) and deduced an EDML thinning function. For the LID, we used the Goujon et al. (2003) densification model forced with the temperature and accumulation estimates as derived from Loulergue et al. (2007, scenario 1). The LID is taken at $5 \%$ of closed porosity.

This method is more precise than a direct evaluation of the $\Delta$ depth at EDC from modelling. Indeed, the accumulation rate is 3 times higher at EDML than at EDC. An error in EDML LID thus has a 3 times lower impact than at EDC in terms of ages. 

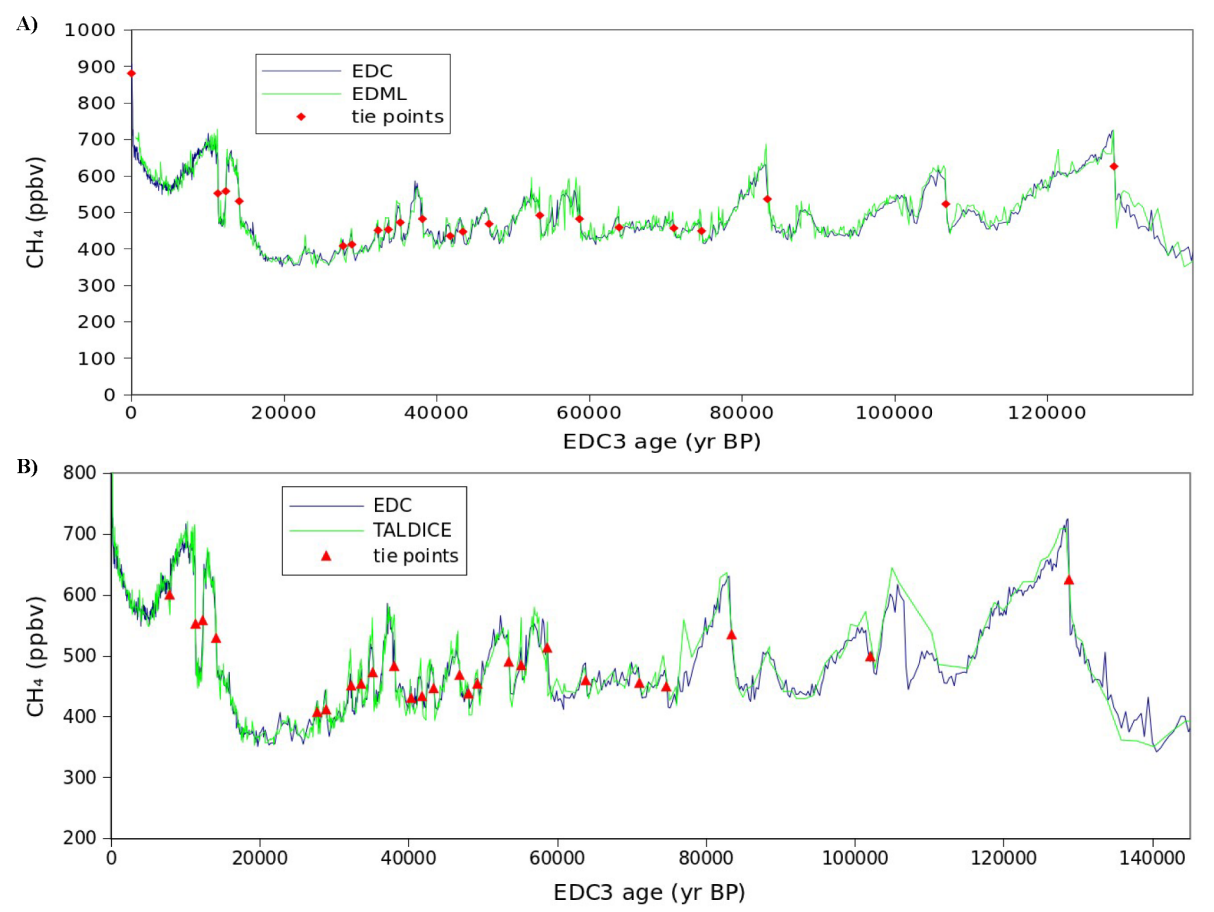

Fig. 6. Gas synchronisation between EDC and EDML (A) and between EDC and TALDICE (B) using the $\mathrm{CH}_{4}$ records (Loulergue et al., 2007, 2008; Schilt et al., 2010; Buiron et al., 2011).

There are 4 sources of uncertainty in this EDML-synchro based approach: (1) the uncertainty in the gas $\left(\mathrm{CH}_{4}\right)$ synchronisation, (2) the uncertainty in the LID estimate at EDML, (3) the uncertainty in the thinning function at EDML, and (4) the uncertainty in the ice (volcanic) synchronisation (including the interpolation between two neighbouring volcanic tie points). We estimate uncertainty (1) $(2 \sigma)$ as half the duration of the $\mathrm{CH}_{4}$ transition. Uncertainty (2) $(2 \sigma)$ is thought to be $<20 \%$ at EDML (Landais et al., 2006), i.e. $<7 \%$ at EDC. Based on the relative duration of events in different glaciological time scales (Parrenin et al., 2007b), we deduce that uncertainty (3) $(2 \sigma)$ is $<10 \%$ (Parrenin et al., 2007b). With the same argument, uncertainty (4) $(2 \sigma)$ is estimated to be $<10 \%$ of the distance to the nearest tie point, i.e. we neglected the uncertainty in the tie points. In order to compute the total uncertainty, we assume uncertainties (1), (2), (3) and (4) to be independent.

Note that a recent study (Köhler, 2010) suggested that aligning the mid-transitions of $\mathrm{CH}_{4}$ in different ice cores induces an error because of the different diffusion times of the gas signals. We consider that this conclusion only applies if one defines the gas age as the minimum gas age of the distribution. We defined here the gas age as the median of the distribution and we are therefore free from such an error.

\section{5 $\Delta$ depth from ice and gas synchronisation to TALDICE}

The method is the same as in the previous sub-section (see Fig. 5). Its advantage is also based on the fact that TALDICE accumulation rate is 3 times higher than EDC accumulation rate. The EDC and TALDICE ice cores can be synchronised in the ice phase using volcanic markers for the last $42 \mathrm{kyr}$ (Severi et al., 2012) and isotopic records for older time periods (Jouzel et al., 2007; Stenni et al., 2011, see Table 2) as well as in the gas phase using the $\mathrm{CH}_{4}$ records (Loulergue et al., 2008; Buiron et al., 2011, see Table 3 and Fig. 6). We do not use the tie points of Buiron et al. (2011) since they are not always placed exactly at mid-transitions. We also restricted the tie point selection to the part of $\mathrm{CH}_{4}$ records bearing the less disputable common structure. We use $\triangle$ age at TALDICE as computed by Buiron et al. (2011).

The uncertainty is calculated in the very same way as for the synchronisation to EDML.

\section{6 $\Delta$ depth from the thermal bipolar seesaw hypothesis}

Following the so-called thermal bipolar seesaw hypothesis (Stocker and Johnsen, 2003), Greenland temperature is related to the derivative of the Antarctic temperature derived from EDC isotopic record (Barker et al., 2011). The most viable mechanism for abrupt climate changes in the North Atlantic region involves reorganizations of the ocean circulation (Stommel, 1961; Ruddiman and McIntyre, 1981) but atmospheric mechanisms may also be at play in the antiphase 
Table 2. Isotopic synchronisation tie points between the TALDICE and EDC99 ice cores.

\begin{tabular}{rr}
\hline Depth-TALDICE & Depth-EDC99 \\
\hline 1160 & 800 \\
1220 & 880 \\
1260 & 950 \\
1285 & 1002 \\
1303 & 1059 \\
1312 & 1100 \\
1331 & 1200 \\
1353 & 1320 \\
1375 & 1449 \\
1411 & 1700 \\
1440 & 1855 \\
1446 & 1889 \\
1463 & 1906 \\
1471 & 1935 \\
1477.5 & 1952.5 \\
1485 & 1981 \\
1493.7 & 2027 \\
1497 & 2048 \\
1508 & 2093 \\
1522.5 & 2170 \\
1528 & 2222 \\
1534 & 2235 \\
1545 & 2295 \\
1582 & 2500 \\
\hline &
\end{tabular}

relationship proven for the last glacial period (Blunier et al., 1998; Blunier and Brook, 2001; EPICA community members, 2006; Capron et al., 2010). Using the seesaw hypothesis, we can consequently synchronise the deuterium content of the EDC ice (a proxy for Antarctic temperature) with the $\mathrm{CH}_{4}$ (Loulergue et al., 2008) content of the EDC gas bubbles (a proxy of Greenland temperature) and produce $\Delta$ depth estimates during periods of fast $\mathrm{CH}_{4}$ variations corresponding to the various maxima or minima in the deuterium record.

To localize the multiple maxima or minima in the deuterium record, we used the synthetic Greenland temperature curve $\mathrm{GL}_{T_{-}}$syn from Barker et al. (2011) calculated from the deuterium record of ice at EDC. This curve was constructed by a mathematical process which involves separation of the high and low frequency components of the Antarctic temperature record and differentiation of the high frequency component before it is recombined with the low frequency component. Identifying an extremum in the EDC deuterium record thus corresponds to identifying a fast transition in the $\mathrm{GL}_{T_{-}}$syn curve. The fact that Barker et al. (2011) were able to reconstruct a curve from an Antarctic ice isotope record which resembles the Greenland ice isotope record and in particular exhibits similar fast transitions is another congruent proof for the validity of the seesaw mechanism.

In Fig. 7, we compare the $\mathrm{GL}_{T_{-}}$syn curve of Barker et al. (2011) and the EDC deuterium record of Jouzel et al. (2007) with the $\mathrm{CH}_{4}$ record from EDC (Loulergue et al.,
Table 3. $\mathrm{CH}_{4}$ synchronisation tie points between EDC and TALDICE and corresponding $\Delta$ depth estimates at EDC.

\begin{tabular}{lrrrr}
\hline Description & $\begin{array}{r}\text { EDC gas } \\
\text { depth }(\mathrm{m})\end{array}$ & $\begin{array}{r}\text { Talos gas } \\
\text { depth }(\mathrm{m})\end{array}$ & $\begin{array}{r}\Delta \text { depth } \\
(\mathrm{m})\end{array}$ & $\begin{array}{r}1 \sigma \text { uncertainty } \\
(\mathrm{m})\end{array}$ \\
\hline 8.2 kyr event & 323 & 553.0 & 64.5 & 4.19 \\
YD-Holo & 418.5 & 695.4 & 64.0 & 4.29 \\
BO/YD & 443.5 & 736.8 & 61.1 & 4.07 \\
onset BA & 476.1 & 785.5 & 57.4 & 4.06 \\
onset DO3 & 639.1 & 941.0 & 55.9 & 3.72 \\
onset DO4 & 651.9 & 953.0 & 58.3 & 3.81 \\
onset DO5 & 688.1 & 990.0 & 52.9 & 3.55 \\
onset DO6 & 702.1 & 1004.0 & 53.6 & 3.53 \\
onset DO7 & 719.7 & 1025.0 & 50.0 & 3.29 \\
onset DO8 & 751.3 & 1059.2 & 50.0 & 3.43 \\
onset DO9 & 776 & 1085.0 & 55.4 & 3.57 \\
onset DO10 & 791.0 & 1098.6 & 56.7 & 3.63 \\
onset DO11 & 809.2 & 1125.0 & 53.2 & 3.56 \\
onset DO12 & 848.5 & 1170.7 & 48.4 & 3.44 \\
onset DO13a & 862.0 & 1183.0 & 46.4 & 3.64 \\
onset DO13b & 876.0 & 1192.0 & 48.7 & 4.37 \\
onset DO14 & 925.0 & 1229.0 & 44.9 & 3.45 \\
onset DO15 & 945.0 & 1239.4 & 48.2 & 3.58 \\
onset DO17 & 986.5 & 1263.3 & 42.0 & 3.05 \\
onset DO18 & 1038.5 & 1286.7 & 42.4 & 3.20 \\
onset DO19 & 1105.0 & 1307.2 & 38.3 & 3.52 \\
onset DO20 & 1142.0 & 1315.1 & 37.3 & 3.67 \\
onset DO21 & 1239.0 & 1333.5 & 35.9 & 4.89 \\
onset DO23 & 1431.5 & 1369.0 & 34.4 & 6.63 \\
onset MIS5.5 & 1722.0 & 1411.2 & 28.8 & 3.42 \\
\hline & & & &
\end{tabular}

2008) on a depth scale. Using these constraints, 82 tie points (see Table 4) are derived between the two records, mainly at times of fast variations in Greenland temperature. These tie points correspond to maxima and minima in the EDC deuterium record (see Fig. 7). $\Delta$ depth estimates are simply computed as the depth of the transition in the methane record minus the depth of the transition in the $\mathrm{GL}_{T_{-}}$syn curve (or equivalently to the depth of the maxima or minima in the deuterium record).

There are two sources of error in this procedure. First, the identified transitions in $\mathrm{GL}_{T-}$ syn and $\mathrm{CH}_{4}$ may not correspond to the same event. We therefore tagged the pairs of tie points as "virtually certain" or "tentative". Second, even if the transitions in $\mathrm{GL}_{T_{-}}$syn and $\mathrm{CH}_{4}$ correspond to the same event, there is an error linked to the determination of the depth of the transitions in both curves. To evaluate this $(2 \sigma)$ error of these $\Delta$ depth estimates, we added the error of the depth estimates of the transition in the methane and $\mathrm{GL}_{T_{-}}$syn curves, respectively. These errors are evaluated as half of the duration of the transition.

The reasons why we used $\mathrm{GL}_{T}$ syn and not the raw deuterium record are: (1) it is easier and more accurate to select a mid-transition than an extremum, and (2) it is also easier to estimate the error in the tie point picking as half of the duration of the transition. 
A)

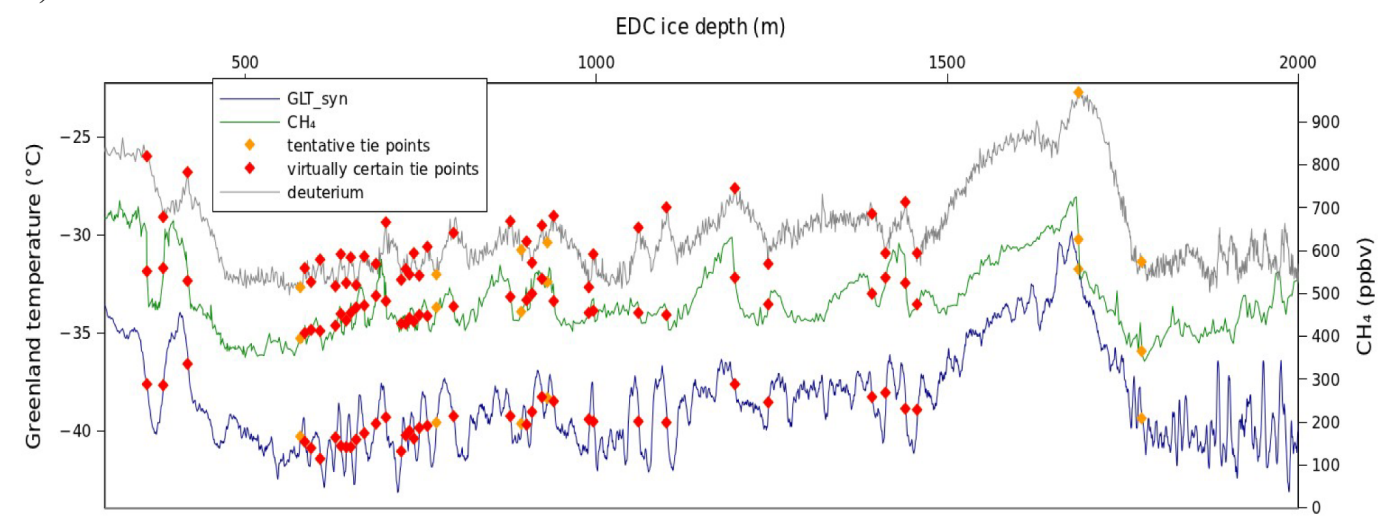

B)

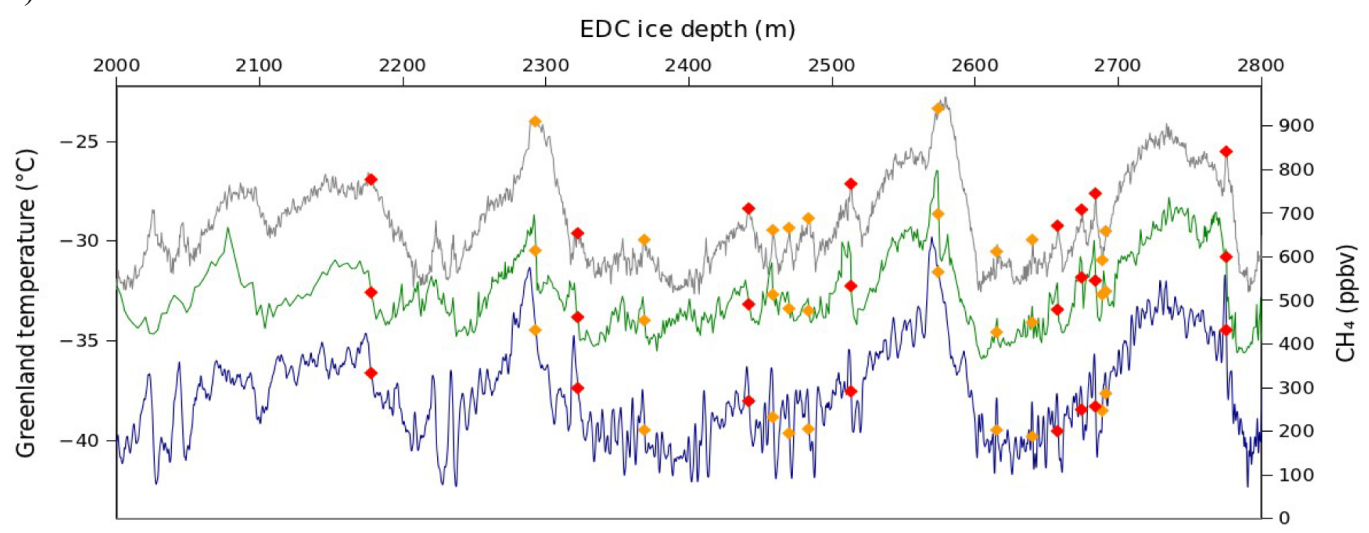

C)

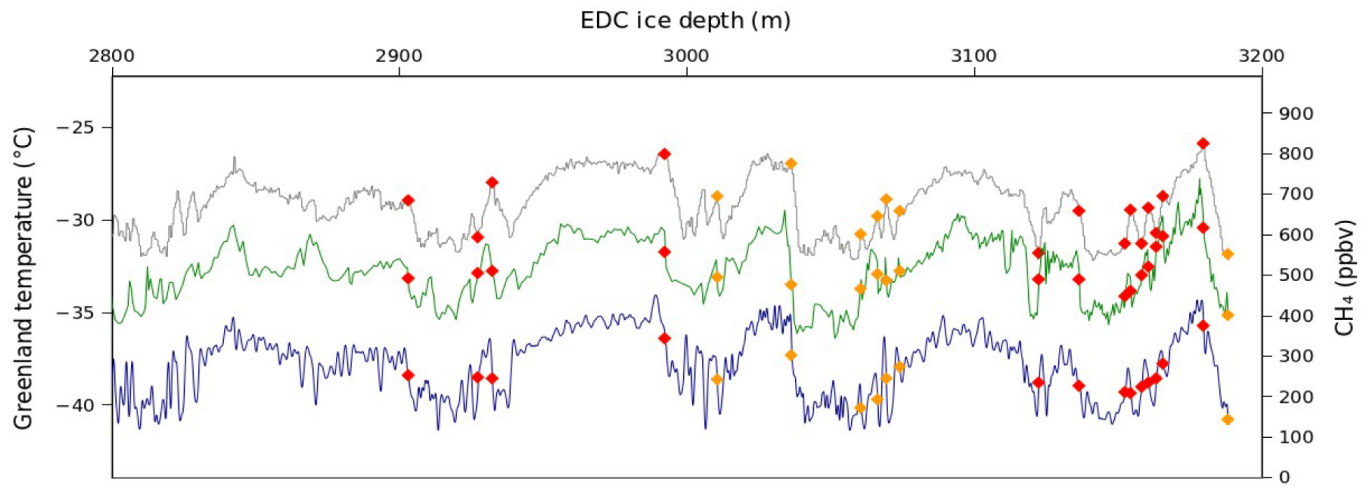

Fig. 7. Comparison between the $\mathrm{GL}_{T_{\mathrm{syn}}}$ curve (Barker et al., 2011), the $\mathrm{EDC} \mathrm{CH}_{4}$ record (Loulergue et al., 2008) and the EDC $\delta \mathrm{D}$ record (Jouzel et al., 2007): (A) in the depth interval 0-2000 m, (B) in the depth interval 2000-2800 m, (C) in the depth interval 2800-3200 m. The deuterium record has been resampled on 100 -yr intervals.

\section{Discussion}

In Fig. 8, we compare the various $\Delta$ depth estimates derived previously. Several conclusions can be outlined.

\subsection{Confirmation of the bipolar seesaw antiphase}

The GRIP-synchro based estimate of $\Delta$ depth during the Laschamp geomagnetic event is the most accurate $( \pm 2 \mathrm{~m})$ and robust (it does not rely on controversial hypotheses) estimate available among the EDC ice core data. It is important to note that this estimate is fully compatible with the bipolar seesaw-based estimate. In other words, the seesaw phasing between EDC and GRIP is observed during the Laschamp geomagnetic event, as was already concluded by Raisbeck et al. (2007).

A second noteworthy remark is that the EDML ice core record mainly confirms the seesaw hypothesis, as was also 
Table 4. Ice-depth/gas-depth synchronisation based on the seesaw method and corresponding $\Delta$ depth along the EDC ice core.

\begin{tabular}{|c|c|c|c|c|c|}
\hline Description & Ice depth (m) & Gas depth (m) & $\Delta$ depth (m) & $1 \sigma(\mathrm{m})$ & Tentative or not \\
\hline YD-Holo & 359.82 & 418.50 & 58.68 & 5.12 & \\
\hline BA-YD & 383.36 & 443.50 & 60.14 & 4.22 & \\
\hline onset BA & 418.83 & 476.10 & 57.27 & 4.86 & \\
\hline end DO3 & 578.22 & 627.00 & 48.78 & 2.66 & tentative \\
\hline onset DO3 & 585.44 & 639.10 & 53.66 & 2.34 & \\
\hline end DO4 & 593.79 & 647.00 & 53.21 & 2.50 & \\
\hline onset DO4 & 607.26 & 651.90 & 44.64 & 2.10 & tentative \\
\hline end DO5 & 629.07 & 681.00 & 51.93 & 2.36 & \\
\hline onset DO5 & 636.90 & 688.10 & 51.20 & 1.80 & \\
\hline end DO6 & 644.07 & 696.00 & 51.93 & 1.95 & \\
\hline onset DO6 & 651.06 & 702.10 & 51.04 & 1.72 & \\
\hline end DO7 & 658.55 & 712.00 & 53.45 & 2.12 & \\
\hline onset DO7 & 669.51 & 719.70 & 50.19 & 2.59 & \\
\hline end DO8 & 686.46 & 732.50 & 46.04 & 3.05 & \\
\hline onset DO8 & 700.51 & 751.30 & 50.79 & 1.90 & \\
\hline end DO9 & 722.40 & 773.30 & 50.90 & 2.24 & \\
\hline onset DO9 & 729.37 & 776.00 & 46.63 & 1.46 & \\
\hline end DO10 & 733.82 & 784.20 & 50.38 & 1.68 & \\
\hline onset DO10 & 740.83 & 791.00 & 50.17 & 1.42 & \\
\hline end DO11 & 748.32 & 800.00 & 51.68 & 2.50 & \\
\hline onset DO11 & 759.81 & 809.20 & 49.39 & 1.98 & \\
\hline end DO12 & 772.34 & 823.00 & 50.66 & 2.83 & tentative \\
\hline onset DO12 & 797.00 & 848.50 & 51.50 & 2.76 & \\
\hline onset DO14 & 878.00 & 925.00 & 47.00 & 1.90 & \\
\hline end DO15 & 894.00 & 935.00 & 41.00 & 1.80 & tentative \\
\hline onset DO15 & 901.00 & 945.00 & 44.00 & 1.25 & \\
\hline end DO16 & 909.00 & 953.00 & 44.00 & 2.12 & \\
\hline onset DO16 & 923.00 & 969.00 & 46.00 & 2.12 & \\
\hline end DO17 & 931.00 & 974.00 & 43.00 & 2.12 & tentative \\
\hline onset DO17 & 940.00 & 986.50 & 46.50 & 1.90 & \\
\hline end DO18 & 990.50 & 1030.00 & 39.50 & 2.30 & \\
\hline onset DO18 & 997.00 & 1038.50 & 41.50 & 1.72 & \\
\hline onset DO19 & 1061.00 & 1105.00 & 44.00 & 1.85 & \\
\hline onset DO20 & 1101.00 & 1142.00 & 41.00 & 2.27 & \\
\hline onset DO21 & 1197.50 & 1239.00 & 41.50 & 2.50 & \\
\hline end DO22 & 1245.50 & 1281.00 & 35.50 & 1.95 & \\
\hline onset DO23 & 1393.00 & 1431.50 & 38.50 & 1.80 & \\
\hline end DO24 & 1413.00 & 1445.00 & 32.00 & 2.50 & \\
\hline onset DO24 & 1441.00 & 1473.00 & 32.00 & 1.95 & \\
\hline end DO25 & 1458.00 & 1485.00 & 27.00 & 2.12 & \\
\hline \multirow[t]{15}{*}{ onset MIS5.5 } & 1687.00 & 1722.00 & 35.00 & 3.64 & tentative \\
\hline & 1777.50 & 1812.00 & 34.50 & 2.02 & tentative \\
\hline & 2178.00 & 2194.00 & 16.00 & 2.12 & \\
\hline & 2293.00 & 2307.00 & 14.00 & 1.58 & tentative \\
\hline & 2322.50 & 2337.00 & 14.50 & 1.60 & \\
\hline & 2369.00 & 2380.00 & 11.00 & 1.25 & tentative \\
\hline & 2442.00 & 2454.00 & 12.00 & 0.90 & \\
\hline & 2459.00 & 2470.00 & 11.00 & 1.12 & tentative \\
\hline & 2470.20 & 2480.50 & 10.30 & 0.71 & tentative \\
\hline & 2484.00 & 2493.50 & 9.50 & 0.71 & tentative \\
\hline & 2513.30 & 2523.30 & 10.00 & 0.71 & \\
\hline & 2574.50 & 2584.70 & 10.20 & 1.30 & tentative \\
\hline & 2615.70 & 2623.30 & 7.60 & 0.38 & tentative \\
\hline & 2640.30 & 2647.70 & 7.40 & 0.25 & tentative \\
\hline & 2658.10 & 2665.50 & 7.40 & 0.39 & \\
\hline
\end{tabular}


Table 4. Continued.

\begin{tabular}{rrrrrl}
\hline Description & Ice depth $(\mathrm{m})$ & Gas depth $(\mathrm{m})$ & $\Delta$ depth $(\mathrm{m})$ & $1 \sigma(\mathrm{m})$ & Tentative or not \\
\hline 2674.80 & 2682.70 & 7.90 & 0.49 & \\
2684.20 & 2691.00 & 6.80 & 0.43 & \\
2688.80 & 2694.90 & 6.10 & 0.57 & tentative \\
2691.70 & 2697.00 & 5.30 & 0.61 & tentative \\
2775.50 & 2780.70 & 5.20 & 0.71 & \\
2903.00 & 2907.00 & 4.00 & 0.71 & \\
2927.50 & 2935.00 & 7.50 & 1.12 & \\
2932.30 & 2941.00 & 8.70 & 0.64 & \\
2992.50 & 2997.80 & 5.30 & 0.64 & \\
3010.50 & 3013.20 & 2.70 & 0.35 & tentative \\
3036.50 & 3038.50 & 2.00 & 0.71 & tentative \\
3060.70 & 3064.90 & 4.20 & 0.29 & tentative \\
3066.30 & 3070.30 & 4.00 & 0.46 & tentative \\
3069.30 & 3074.30 & 5.00 & 0.43 & tentative \\
3074.00 & 3078.70 & 4.70 & 0.40 & tentative \\
3122.40 & 3124.00 & 1.60 & 0.35 & \\
3136.50 & 3139.50 & 3.00 & 0.56 & \\
3152.50 & 3157.50 & 5.00 & 0.35 & \\
3154.50 & 3159.10 & 4.60 & 0.35 & \\
3158.20 & 3162.20 & 4.00 & 0.57 & \\
3160.70 & 3164.40 & 3.70 & 0.43 & \\
3163.30 & 3167.00 & 3.70 & 0.61 & \\
3165.70 & 3169.00 & 3.30 & 0.35 & \\
3179.70 & 3182.60 & 2.90 & 0.39 & \\
& & & &
\end{tabular}

stated recently (EPICA community members, 2006; Capron et al., 2010). One can, however, remark that the EDML synchro estimates tend to underestimate $\Delta$ depth during the last glacial period with respect to the seesaw-based estimates by $\sim 2-3 \mathrm{~m}$ in average, probably resulting from an underestimation of $\Delta$ depth at EDML, as systematic offsets in both the $\mathrm{CH}_{4}$ and volcanic synchronisations are unlikely. An underestimated LID by the densification model is also unlikely because $\delta^{15} \mathrm{~N}$ data shows the contrary (Landais et al., 2006). It thus leaves us only with an underestimation of EDML thinning, which may be due to an overestimation of EDML accumulation rates during the glacial. We indeed did not take into account the fact that accumulation rates are lower upstream of the EDML site from where the ice supposedly originates (Huybrechts et al., 2007).

A third remark, arising from the present study, is that the TALDICE ice core records confirm the seesaw hypothesis. Contrary to the EDML ice core, we did not observe for the TALDICE ice core a systematic offset with respect to the seesaw-based estimates. As a consequence, the TALDICEsynchro method overestimates $\Delta$ depth with respect to the EDML-synchro method.

In the detail, there are EDML-based or TALDICE-based estimates which significantly deviate from the seesaw-based estimates. Note that we used exactly the same depths for the $\mathrm{CH}_{4}$ transitions in all three methods. At $\sim 651.90 \mathrm{~m}$ (onset of DO4), the seesaw-based estimate is very small
(44.64 $\mathrm{m}$ ) compared to the EDML-based and TALDICEbased estimates. The corresponding maxima in the deuterium curve is ambiguous and it is why this tie point has been tagged as "tentative". Another possible explanation is that EDC3 underestimates the duration of events in this interval, leading to overestimated thinning function at EDML and TALDICE. At $809.2 \mathrm{~m}$ (onset DO11) and $848.5 \mathrm{~m}$ (onset DO12), the TALDICE-based estimates are very small $(53.23 \mathrm{~m}$ and $48.42 \mathrm{~m})$ compared to the EDML-based and seesaw-based estimates. We note however that we are here beyond the EDC-TALDICE volcanic synchronisation, so this discrepancy can come from a poor EDC-TALDICE ice synchronisation. At $1105 \mathrm{~m}, 1142 \mathrm{~m}, 1239 \mathrm{~m}, 1431.5 \mathrm{~m}$ and $1473 \mathrm{~m}$ (onsets DO19, 20, 21, 23 and 24), the seesaw-based estimates are systematically higher than the EDML-based and TALDICE-based estimates. One possible explanation is that EDML and TALDICE $\triangle$ depths are underestimated due to an overestimation of durations in EDC3.

\subsection{The "glacial $\Delta$ depth paradox at EDC"}

Focusing now on the modelling estimates of $\Delta$ depth during the last glacial period (the last deglaciation and the last glacial period), they are on average $\sim 15 \%$ larger than the seesaw-based estimates or the EDML-synchro and TALDICE-synchro based estimates. It is very likely that the modelled $\Delta$ depth is inaccurate during this time period. We 
A)

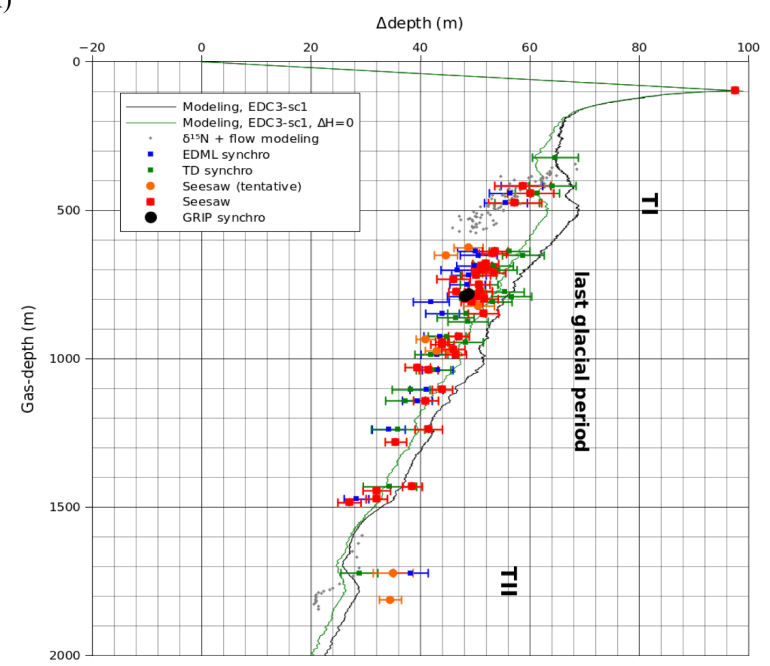

B)

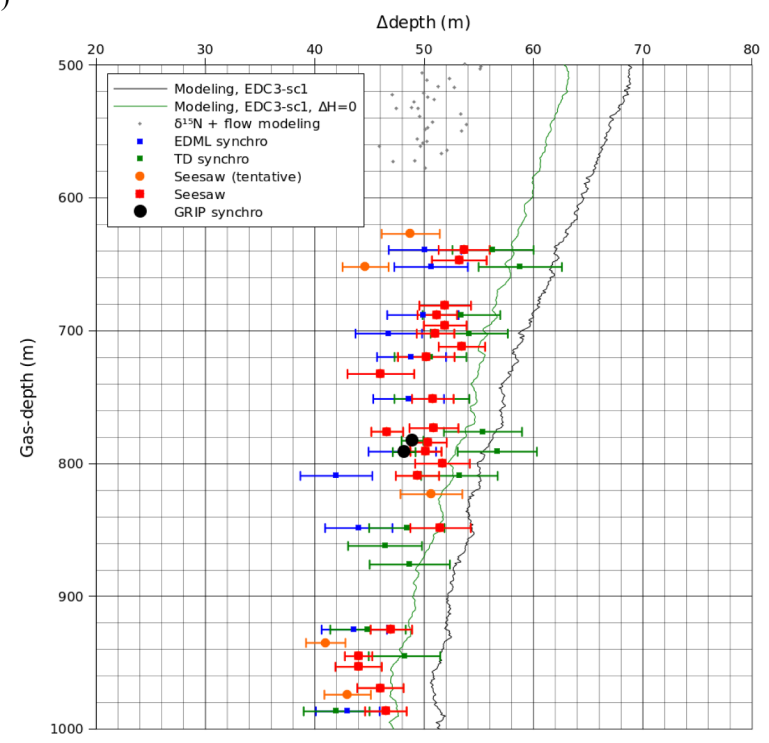

Fig. 8. $\Delta$ depth estimates along the EDC ice core. (A) Zoom on the 0-2000 m depth interval, which shows the glacial and termination II $\Delta$ depth paradoxes. (B) Zoom on the 500-1000 m depth interval encompassing the Laschamp event. The error bars have to be taken as $1 \sigma$ uncertainty.

call this model-data discrepancy the "glacial $\Delta$ depth paradox at EDC". This may be due either to an overestimation of the thinning function or to an overestimation of the LID.

One factor influencing the thinning function is the existence of non-laminar flow effects. However, the amplitude of the $\Delta$ depth paradox is greater than the uncertainty on the thinning function due to non-laminar flow effects (Fig. 2).

Another factor which has a significant impact on the thinning function in the upper part of the ice sheet is the past variation of ice thickness. As previously explained, apart from the EDC3 scenario of past ice thickness variations, we tested a scenario without ice thickness variations as an extreme case
C)

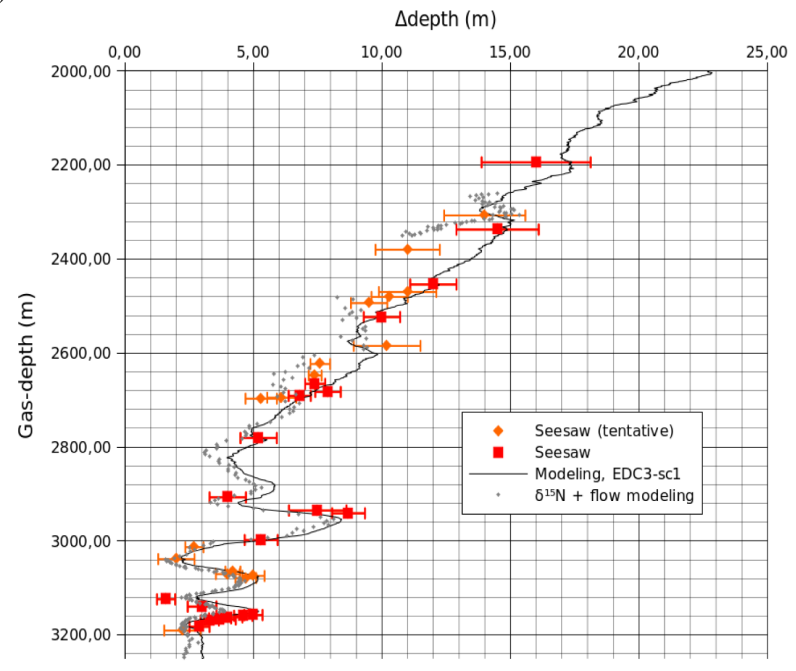

Fig. 8. (C) Zoom on the 2000-3200 m depth interval.

(see Fig. 8). This scenario only partially solves the glacial $\Delta$ depth paradox at EDC.

The last factor that has a significant impact on the thinning function in the shallow part is the ice thickness at the site of snow deposition. The glacial $\Delta$ depth paradox at EDC could be solved if one assumes that the ice flow was not vertical in the past and that the ice originates from a site with greater ice thickness. This hypothesis is difficult to test from a modelling point of view because there are many unknown parameters in 3-D ice flow models of the Antarctic ice sheet influencing the position of the ridges and of the domes. We however remark here that the glacial $\Delta$ depth paradox at EDC only concerns the glacial part and is not present (and is even inverted) for the Eemian ice. This paradox therefore seems to have a climatic origin. Our conclusion is thus that, for reasons which are beyond the scope of the present manuscript, the firn densification model overestimates the glacial LID at EDC. A possible explanation is the effect of impurities on the densification process (Hörhold et al., 2012).

This remark is in contradiction with the conclusions of Caillon et al. (2003), who stated that the firn densification model correctly estimated $\Delta$ age at Vostok during Termination III. However, Caillon et al. (2003) based their conclusions on the assumption that, at Vostok, $\delta^{40} \mathrm{Ar}$ varies in phase with temperature, which has never been demonstrated. If, as proposed by Hörhold et al. (2012), the densification velocity (and thus the gravitational fractionation) is influenced by impurities, $\delta^{40} \mathrm{Ar}$ should be better correlated with the impurity record than with the ice isotopic record when both are not in phase (Röthlisberger et al., 2008). Moreover, their conclusion suffers from the poorly known thinning function at Vostok at the depth corresponding to Termination III. 


\subsection{The "Termination II $\Delta$ depth paradox at EDC"}

During Termination II, we have two different estimates of the $\Delta$ depth (see Fig. 8a, depth interval 1700-1800 m). On one hand, the model-based estimate suggests a relatively low $\Delta$ depth. On the other hand, the seesaw method roughly agrees with the EDML-synchro and TALDICEsynchro methods and suggests a relatively high $\Delta$ depth (we should note however that the two seesaw points are only tentative at this stage). We call this discrepancy the "Termination II $\Delta$ depth paradox at EDC".

There are two possible explanations for this discrepancy. Either the seesaw phenomenon is not at work during the penultimate deglaciation, unlike the last glacial period, and the EDML-synchro and TALDICE-synchro methods are not precise during this time period; or the modelled estimates are too low.

One possibility to reconcile the model with the seesawbased estimates would be to increase the thinning function, which would have the side effect to decrease the duration of the penultimate interglacial in EDC and to give a better agreement with the duration of this stage in the Dome Fuji ice core (Parrenin et al., 2007b). Another possibility would be to increase the LIDIE, for example by assuming that the surface temperature has been underestimated during this time period. It is indeed not clear that the deuterium-temperature spatial relationships used remain valid for climates warmer than the present (Sime et al., 2009).

\subsection{Using $\Delta$ depth estimates in the deepest part to improve the EDC age scale}

For the depth interval 2000-2800 m, $\Delta$ depth estimates regularly decrease from $\sim 16 \mathrm{~m}$ to $\sim 5 \mathrm{~m}$. In this depth interval, the agreement between the seesaw-based and model-based based estimates is surprisingly good. The fact that the model does not systematically overestimate the $\Delta$ depth in this depth interval, contrary to the last glacial period, may be just a coincidence: an overestimated LIDIE may be exactly compensated by an underestimated thinning function.

For the depth interval $2800-3200 \mathrm{~m}$, the agreement is also good. In particular, the seesaw-based $\Delta$ depth estimates reproduce well the bumps in the thinning function, which have been suggested based on the comparison between ${ }^{18} \mathrm{O}_{\text {atm }}$ measurements and insolation variations and based on the phasing between $\delta D$ and $\mathrm{CO}_{2}$ (Dreyfus et al., 2007). We thus independently confirm the hypothesis that the flow in the bottom part of the EDC ice core is complex.

There are however several seesaw-based estimates which deviate significantly from the model-based estimates at $\sim 2360 \mathrm{~m}$ (tentative tie point, $\sim 260 \mathrm{kyr}$ ), $\sim 2900 \mathrm{~m}$ $(\sim 527 \mathrm{kyr}), \sim 2930 \mathrm{~m}(554 \mathrm{kyr}), \sim 3000 \mathrm{~m}(\sim 585 \mathrm{kyr})$ and $\sim 3120 \mathrm{~m}(\sim 719 \mathrm{kyr})$. This is somewhat in agreement with results by Landais et al. (2012) based on the tuning of the $\mathrm{O}_{2} / \mathrm{N}_{2}$ record on local insolation variations. They indeed suggested corrections of up to $\sim 5 \mathrm{kyr}$ for the time period $390-460 \mathrm{kyr}, 550 \mathrm{kyr}, 650 \mathrm{kyr}$ and $750 \mathrm{kyr}$ BP.

In conclusion, we thus suggest that using these seesawbased estimates associated with new $\mathrm{O}_{2} / \mathrm{N}_{2}$ measurements could improve the reconstruction of the thinning function and thus the evaluation of the EDC chronology in the deep part.

\subsection{Validity of the $\delta^{15} \mathrm{~N}$ firn thickness estimate for the last deglaciation}

The $\delta^{15} \mathrm{~N}$ record in association with the thinning model gives an evaluation of the $\Delta$ depth decreasing from $67 \mathrm{~m}$ to $45 \mathrm{~m}$ during the course of the last deglaciation. In this upper part of the EDC ice core, the uncertainty in the thinning function is thought to be small (Fig. 2). These $\Delta$ depth estimates are in good agreement with the estimates based on the synchronisation to EDML and TALDICE or based on the seesaw hypothesis (Fig. 8). If there are no other compensating effects, the convective zone cannot be more than a few metres at EDC during the last deglaciation. Consequently, we conclude that the model $-\delta^{15} \mathrm{~N}$ data mismatch observed at EDC during the last deglaciation (Dreyfus et al., 2010) probably results from an incorrect representation of the densification process in firn models (Hörhold et al., 2012), and not to a varying convective height or to poorly known $\delta^{15} \mathrm{~N}$ fractionation processes (Dreyfus et al., 2010).

This conclusion seems in contradiction with a study on the Vostok ice core using ice and gas synchronisation to Byrd (Bender et al., 2006), which concluded that $\delta^{15} \mathrm{~N}$ underestimates the LID during the last glacial period. However, concerning this study, we note that: (1) there is no estimate of uncertainty in the Byrd-synchro method; (2) the thinning function reconstruction is a lot more uncertain than in our case because the coring point at Vostok is not situated on a dome (Parrenin et al., 2004); (3) the ice synchronisation is less precise than in our study because it is based on the ice isotope data; and (4) the gas synchronisation is also less precise because it is based on a smaller number of $\mathrm{CH}_{4}$ measurements.

Consequently, the $\delta^{15} \mathrm{~N}$ data seems to be a more appropriate tool as compared to the current densification models used to estimate the LID during the last deglaciation at EDC. Is this conclusion valid for other time periods and for other Antarctic sites where a model- $\delta^{15} \mathrm{~N}$ data mismatch has been observed, such as Vostok (Sowers et al., 1992; Caillon et al., 2003), EDML (Landais et al., 2006), Law Dome (Landais et al., 2006) and Dome Fuji (Severinghaus et al., 2010, based on the data by Kawamura, 2000)? Further studies following the approach presented here are needed to answer this question.

\section{Conclusions}

We have shown that the bipolar seesaw antiphase relationship is generally supported by the ice-gas cross synchronisation of EDC to the GRIP, EDML and TALDICE ice cores. The 
glaciological model overestimates the glacial $\Delta$ depth at EDC (we called this the "glacial $\Delta$ depth paradox at EDC") and this is probably due to an overestimation of the glacial closeoff depth by the firn densification model. The glaciological models seem to underestimate the $\Delta$ depth during Termination II (we called this the "Termination II $\Delta$ depth paradox at EDC"). We have shown that the bipolar seesaw hypothesis confirms that the ice flow is complex in the deep part of the EDC ice core and can help improve the EDC age scale. For the last deglaciation, using $\delta^{15} \mathrm{~N}$ data in association with an ice flow model gives $\Delta$ depth estimates in agreement with the estimates based on the synchronisation to TALDICE and EDML or based on the seesaw method.

Complete, precise and highly resolved $\delta^{15} \mathrm{~N}$ and $\mathrm{CH}_{4}$ records will be necessary to further improve the EDC gas and ice age scales. An automatic method to synchronise records would both bring rigour and shorten the time to accomplish this tedious task. Further studies will be needed to make the firn densification models more useful for paleoclimatic studies using the Antarctic ice core records. Both the firn modelling and $\delta^{15} \mathrm{~N}$ approaches need a precise evaluation of the past surface and lock-in densities and further studies are needed to better constrain them. ${ }^{10} \mathrm{Be}$ measurements are in progress and should allow to extend the Antarctic-Greenland ice synchronisation and thus produce more $\Delta$ depth estimates based on this hypothesis-free approach. Studies on the $\Delta$ depth comparable to the present one could be applied to other low accumulation Antarctic ice cores such as Vostok and Dome Fuji. This study on the gas/ice depth offset at EDC has important implications on the phasing between $\mathrm{CO}_{2}$ and Antarctic temperature during climatic changes and consequently on the role of $\mathrm{CO}_{2}$ during these climatic changes.

Acknowledgements. We thank E. Lefebvre, J. M. Barnola and L. Arnaud for the EDC firn temperature data (INSU-CNRS program "Méso Équipement Glaciologie Concordia" and IPEV program 902 Glaciologie), G. Dreyfus for measuring the $\delta^{15} \mathrm{~N}$ data and for helpful comments to the manuscript, E. Capron for helpful comments to the manuscript and M. Sacchettini for computing support. This work benefited from support from the French Agence Nationale de la Recherche (project ANR-07-BLAN-0125 "Dome A" and ANR-09-SYSC-001 "ADAGE"). This work is a contribution to the European Project for Ice Coring in Antarctica (EPICA), a joint European Science Foundation/European Commission scientific program, funded by the EU and by national contributions from Belgium, Denmark, France, Germany, Italy, the Netherlands, Norway, Sweden, Switzerland and the United Kingdom. The main logistic support was provided by IPEV and PNRA at Dome C. We thank the technical teams in the field and at the labs. This is EPICA publication no. $\mathrm{xx}$.

Edited by: E. Wolff

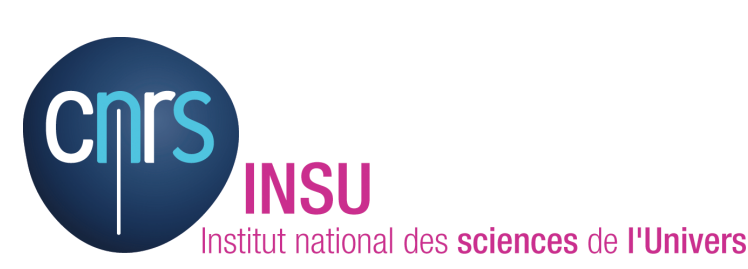

The publication of this article is financed by CNRS-INSU.

\section{References}

Arnaud, L., Barnola, J.-M., and Duval, P.: Physical modeling of the densification of snow/firn and ice in the upper part of polar ice sheets, in: Physics of Ice Core Records, edited by: Hondoh, T., Hokkaido University Press, Sapporo, Japan, 285-305, 2000.

Barker, S., Knorr, G., Edwards, R. L., Parrenin, F., Putnam, A. E., Skinner, L. C., Wolff, E., and Ziegler, M.: 800,000 Years of Abrupt Climate Variability, Science, 334, 347-351, 2011.

Bender, M. L., Sowers, T., Barnola, J., and Chappellaz, J.: Changes in the $\mathrm{O}_{2} / \mathrm{N}_{2}$ ratio of the atmosphere during recent decades reflected in the composition of air in the firn at Vostok Station, Antarctica, Geophys. Res. Lett., 21, 189-192, 1994.

Bender, M. L., Floch, G., Chappellaz, J., Suwa, M., Barnola, J.-M., Blunier, T., Dreyfus, G., Jouzel, J., and Parrenin, F.: Gas age-ice age differences and the chronology of the Vostok ice core, 0-100 ka, J. Geophys. Res., 111, D21115, doi:10.1029/2005JD006488, 2006.

Blunier, T. and Brook, E. J.: Timing of millennial-scale climate change in Antarctica and Greenland during the last glacial period, Science, 291, 109-112, 2001.

Blunier, T., Chappellaz, J., Schwander, J., Dällenbach, A., Stauffer, B., Stocker, T., Raynaud, D., Jouzel, J., Clausen, H., Hammer, C., and Johnsen, S.: Asynchrony of Antarctic and Greenland climate change during the last glacial period, Nature, 394, 739-743, 1998.

Blunier, T., Schwander, J., Chappellaz, J., Parrenin, F., and Barnola, J.-M.: What was the surface temperature in central Antarctica during the last glacial maximum?, Earth Planet. Sc. Lett., 218, 379-388, 2004.

Buiron, D., Chappellaz, J., Stenni, B., Frezzotti, M., Baumgartner, M., Capron, E., Landais, A., Lemieux-Dudon, B., MassonDelmotte, V., Montagnat, M., Parrenin, F., and Schilt, A.: TALDICE - 1 age scale of the Talos Dome deep ice core, East Antarctica, Clim. Past, 7, 1-16, doi:10.5194/cp-7-1-2011, 2011.

Buizert, C., Martinerie, P., Petrenko, V. V., Severinghaus, J. P., Trudinger, C. M., Witrant, E., Rosen, J. L., Orsi, A. J., Rubino, M., Etheridge, D. M., Steele, L. P., Hogan, C., Laube, J. C., Sturges, W. T., Levchenko, V. A., Smith, A. M., Levin, I., Conway, T. J., Dlugokencky, E. J., Lang, P. M., Kawamura, K., Jenk, T. M., White, J. W. C., Sowers, T., Schwander, J., and Blunier, T.: Gas transport in firn: multiple-tracer characterisation and model intercomparison for NEEM, Northern Greenland, Atmos. Chem. Phys., 12, 4259-4277, doi:10.5194/acp-12-4259-2012, 2012. 
Caillon, N., Severinghaus, J. P., Jouzel, J., Barnola, J.-M., Kang, J., and Lipenkov, V. Y.: Timing of Atmospheric $\mathrm{CO}_{2}$ and Antarctic Temperature Changes Across Termination III, Science, 299, 1728-1731, 2003.

Capron, E., Landais, A., Chappellaz, J., Schilt, A., Buiron, D., Dahl-Jensen, D., Johnsen, S. J., Jouzel, J., Lemieux-Dudon, B., Loulergue, L., Leuenberger, M., Masson-Delmotte, V., Meyer, H., Oerter, H., and Stenni, B.: Millennial and sub-millennial scale climatic variations recorded in polar ice cores over the last glacial period, Clim. Past, 6, 345-365, doi:10.5194/cp-6-3452010, 2010.

Colbeck, S.: Air movement in snow due to windpumping, J. Glaciol., 35, 209-213, 1989.

Colbeck, S.: Model of wind pumping for layered snow, J. Glaciol., 43, 60-65, 1997.

Courville, Z. R., Albert, M. R., Fahnestock, M. A., Cathles IV, L. M., and Shuman, C. A.: Impacts of an accumulation hiatus on the physical properties of firn at a low-accumulation polar site, J. Geophys. Res., 112, F02030, doi:10.1029/2005JF000429, 2007.

Craig, H., Horibe, Y., and Sowers, T.: Gravitational Separation of Gases and Isotopes in Polar Ice Caps, Science, 242, 1675-1678, 1988.

Denton, G. H., Bockheim, J. G., Wilson, S. C., and Stuiver, M.: Late Wisconsin and early Holocene glacial history, inner Ross Embayment, Antarctica, Quaternary Res., 31, 151-182, 1989.

Dreyfus, G. B., Parrenin, F., Lemieux-Dudon, B., Durand, G., Masson-Delmotte, V., Jouzel, J., Barnola, J.-M., Panno, L., Spahni, R., Tisserand, A., Siegenthaler, U., and Leuenberger, M.: Anomalous flow below $2700 \mathrm{~m}$ in the EPICA Dome C ice core detected using $\delta^{18} \mathrm{O}$ of atmospheric oxygen measurements, Clim. Past, 3, 341-353, doi:10.5194/cp-3-341-2007, 2007.

Dreyfus, G. B., Jouzel, J., Bender, M. L., Landais, A., MassonDelmotte, V., and Leuenberger, M.: Firn processes and $\delta^{15} \mathrm{~N}$ : potential for a gas-phase climate proxy, Quaternary Sci. Rev., 29, 28-42, 2010.

EPICA community members: One-to-one coupling of glacial climate variability in Greenland and Antarctica, Nature, 444, 195198, 2006.

Fischer, H., Wahlen, M., Smith, J., Mastroianni, D., and Deck, B.: Ice Core Records of Atmospheric $\mathrm{CO}_{2}$ Around the Last Three Glacial Terminations, Science, 283, 1712-1714, 1999.

Flückiger, J., Blunier, T., Stauffer, B., Chappellaz, J., Spahni, R., Kawamura, K., Schwander, J., Stocker, T. F., and Dahl-Jensen, D.: $\mathrm{N}_{2} \mathrm{O}$ and $\mathrm{CH}_{4}$ variations during the last glacial epoch: Insight into global processes, Global Biogeochem. Cy., 18, 1020, doi:10.1029/2003GB002122, 2004.

Goujon, C., Barnola, J.-M., and Ritz, C.: Modeling the densification of polar firn including heat diffusion: application to close-off characteristics and gas isotopic fractionation for Antarctica and Greenland sites, J. Geophys. Res., 108, 4792, doi:10.1029/2002JD003319, 2003.

Grachev, A. M. and Severinghaus, J. P.: Laboratory determination of thermal diffusion constants for $29^{\circ} \mathrm{N} / 28^{\circ} \mathrm{N}$ in air at temperatures from -60 to $0^{\circ} \mathrm{C}$ for reconstruction of magnitudes of abrupt climate changes using the ice core fossil-air paleothermometer, Geochim. Cosmochim. Ac., 67, 345-360, 2003.

Herron, M. M. and Langway, C. C.: Firn densification: an empirical model, J. Glaciol., 25, 373-385, 1980.
Huber, C., Leuenberger, M., Spahni, R., Flückiger, J., Schwander, J., Stocker, T. F., Johnsen, S., Landais, A., and Jouzel, J.: Isotope calibrated Greenland temperature record over Marine Isotope Stage 3 and its relation to $\mathrm{CH}_{4}$, Earth Planet. Sc. Lett., 243, 504-519, 2006.

Huybrechts, P., Rybak, O., Pattyn, F., Ruth, U., and Steinhage, D.: Ice thinning, upstream advection, and non-climatic biases for the upper $89 \%$ of the EDML ice core from a nested model of the Antarctic ice sheet, Clim. Past, 3, 577-589, doi:10.5194/cp-3577-2007, 2007.

Hörhold, M., Laepple, T., Freitag, J., Bigler, M., Fischer, H., and Kipfstuhl, S.: On the impact of impurities on the densification of polar firn, Earth Planet. Sc. Lett., 325-326, 93-99, 2012.

Jouzel, J., Masson-Delmotte, V., Cattani, O., Dreyfus, G., Falourd, S., Hoffmann, G., Minster, B., Nouet, J., Barnola, J. M., Chappellaz, J., Fischer, H., Gallet, J. C., Johnsen, S., Leuenberger, M., Loulergue, L., Luethi, D., Oerter, H., Parrenin, F., Raisbeck, G., Raynaud, D., Schilt, A., Schwander, J., Selmo, E., Souchez, R., Spahni, R., Stauffer, B., Steffensen, J. P., Stenni, B., Stocker, T. F., Tison, J. L., Werner, M., and Wolff, E. W.: Orbital and Millennial Antarctic Climate Variability over the Past 800,000 Years, Science, 317, 793-796, 2007.

Kawamura, K.: Variations of atmospheric components over the past 340000 years from Dome Fuji deep ice core, Antarctica, PhD thesis, Tohoku University, 2000.

Kawamura, K., Severinghaus, J. P., Ishidoya, S., Sugawara, S., Hashida, G., Motoyama, H., Fujii, Y., Aoki, S., and Nakazawa, T.: Convective mixing of air in firn at four polar sites, Earth Planet. Sc. Lett., 244, 672-682, 2006.

Köhler, P.: Rapid changes in ice core gas records - Part 1: On the accuracy of methane synchronisation of ice cores, Clim. Past Discuss., 6, 1453-1471, doi:10.5194/cpd-6-1453-2010, 2010.

Krinner, G., Raynaud, D., Doutriaux, C., and Dang, H.: Simulations of the Last Glacial Maximum ice sheet surface climate: Implications for the interpretation of ice core air content, J. Geophys. Res., 105, 2059-2070, 2000.

Landais, A., Barnola, J., Kawamura, K., Caillon, N., Delmotte, M., Ommen, T. V., Dreyfus, G., Jouzel, J., Masson-Delmotte, V., Minster, B., Freitag, J., Leuenberger, M., Schwander, J., Huber, C., Etheridge, D., and Morgan, V.: Firn-air $\delta^{16} \mathrm{~N}$ in modern polar sites and glacial-interglacial ice: a model-data mismatch during glacial periods in Antarctica?, Quaternary Sci. Rev., 25, 49-62, 2006.

Landais, A., Dreyfus, G., Capron, E., Pol, K., Loutre, M. F., Raynaud, D., Lipenkov, V. Y., Arnaud, L., Masson-Delmotte, V., Paillard, D., Jouzel, J., and Leuenberger, M.: Towards orbital dating of the EPICA Dome $\mathrm{C}$ ice core using $\delta \mathrm{O}_{2} / \mathrm{N}_{2}$, Clim. Past, 8 , 191-203, doi:10.5194/cp-8-191-2012, 2012.

Lliboutry, L.: A critical review of analytical approximate solutions for steady state velocities and temperature in cold ice sheets, $\mathrm{Z}$. Gletscherkd. Glacialgeol., 15, 135-148, 1979.

Loulergue, L., Parrenin, F., Blunier, T., Barnola, J.-M., Spahni, R., Schilt, A., Raisbeck, G., and Chappellaz, J.: New constraints on the gas age-ice age difference along the EPICA ice cores, 0-50 kyr, Clim. Past, 3, 527-540, doi:10.5194/cp-3-527-2007, 2007.

Loulergue, L., Schilt, A., Spahni, R., Masson-Delmotte, V., Blunier, T., Lemieux, B., Barnola, J. M., Raynaud, D., Stocker, T. F., and Chappellaz, J.: Orbital and millennial-scale features of atmo- 
spheric $\mathrm{CH}_{4}$ over the past 800,000 years, Nature, 453, 383-386, 2008.

Lüthi, D., Floch, M. L., Bereiter, B., Blunier, T., Barnola, J.-M., Siegenthaler, U., Raynaud, D., Jouzel, J., Fischer, H., Kawamura, K., and Stocker, T. F.: High-resolution carbon dioxide concentration record 650,000-800,000 years before present, Nature, 453, 379-382, 2008.

Martinerie, P., Raynaud, D., Etheridge, D. M., Barnola, J.-M., and Mazaudier, D.: Physical and climatic parameters which influence the air content in polar ice, Earth Planet. Sc. Lett., 112, 1-13, 1992.

Martinerie, P., Lipenkov, V. Y., Raynaud, D., Chappellaz, J., Barkov, N. I., and Lorius, C.: Air content paleo record in the Vostok ice core (Antarctica): A mixed record of climatic and glaciological parameters, J. Geophys. Res., 99, 10565-10576, 1994.

Masson-Delmotte, V., Hou, S., Ekaykin, A., Jouzel, J., Aristarain, A., Bernardo, R. T., Bromwich, D., Cattani, O., Delmotte, M., Falourd, S., Frezzotti, M., Gallée, H., Genoni, L., Isaksson, E., Landais, A., Helsen, M. M., Hoffmann, G., Lopez, J., Morgan, V., Motoyama, H., Noone, D., Oerter, H., Petit, J. R., Royer, A., Uemura, R., Schmidt, G. A., Schlosser, E., Simões, J. C., Steig, E. J., Stenni, B., Stievenard, M., van den Broeke, M. R., van de Wal, R. S. W., van de Berg, W. J., Vimeux, F., and White, J. W. C.: A Review of Antarctic Surface Snow Isotopic Composition: Observations, Atmospheric Circulation, and Isotopic Modeling*, J. Climate, 21, 3359-3387, 2008.

Monnin, E., Indermuhle, A., Dallenbach, A., Fluckiger, J., Stauffer, B., Stocker, T. F., Raynaud, D., and Barnola, J.-M.: Atmospheric $\mathrm{CO}_{2}$ concentrations over the last glacial termination, Science, 291, 112-114, 2001.

Parrenin, F. and Hindmarsh, R.: Influence of a non-uniform velocity field on isochrone geometry along a steady flowline of an ice sheet, J. Glaciol., 53, 612-622, 2007.

Parrenin, F., Remy, F., Ritz, C., Siegert, M., and Jouzel, J.: New modelling of the Vostok ice flow line and implication for the glaciological chronology of the Vostok ice core, J. Geophys. Res., 109, D20102, doi:10.1029/2004JD004561, 2004.

Parrenin, F., Dreyfus, G., Durand, G., Fujita, S., Gagliardini, O., Gillet, F., Jouzel, J., Kawamura, K., Lhomme, N., MassonDelmotte, V., Ritz, C., Schwander, J., Shoji, H., Uemura, R., Watanabe, O., and Yoshida, N.: 1-D-ice flow modelling at EPICA Dome C and Dome Fuji, East Antarctica, Clim. Past, 3, 243-259, doi:10.5194/cp-3-243-2007, 2007a.

Parrenin, F., Barnola, J.-M., Beer, J., Blunier, T., Castellano, E., Chappellaz, J., Dreyfus, G., Fischer, H., Fujita, S., Jouzel, J., Kawamura, K., Lemieux-Dudon, B., Loulergue, L., MassonDelmotte, V., Narcisi, B., Petit, J.-R., Raisbeck, G., Raynaud, D., Ruth, U., Schwander, J., Severi, M., Spahni, R., Steffensen, J. P., Svensson, A., Udisti, R., Waelbroeck, C., and Wolff, E.: The EDC3 chronology for the EPICA Dome C ice core, Clim. Past, 3, 485-497, doi:10.5194/cp-3-485-2007, 2007b.

Parrenin, F., Petit, J.-R., Masson-Delmotte, V., Wolff, E., BasileDoelsch, I., Jouzel, J., Lipenkov, V., Rasmussen, S. O., Schwander, J., Severi, M., Udisti, R., Veres, D., and Vinther, B. M.: Volcanic synchronisation between the EPICA Dome C and Vostok ice cores (Antarctica) 0-145 kyr BP, Clim. Past, 8, 1031-1045, doi:10.5194/cp-8-1031-2012, 2012.

Pedro, J. B., Rasmussen, S. O., and van Ommen, T. D.: Rapid coupling of Antarctic temperature and atmospheric $\mathrm{CO}_{2}$ during deglaciation, Clim. Past Discuss., 8, 621-636, doi:10.5194/cpd8-621-2012, 2012.

Pol, K., Debret, M., Masson-Delmotte, V., Capron, E., Cattani, O., Dreyfus, G., Falourd, S., Johnsen, S., Jouzel, J., Landais, A., Minster, B., and Stenni, B.: Links between MIS 11 millennial to sub-millennial climate variability and long term trends as revealed by new high resolution EPICA Dome $\mathrm{C}$ deuterium data - A comparison with the Holocene, Clim. Past, 7, 437-450, doi:10.5194/cp-7-437-2011, 2011.

Raisbeck, G. M., Yiou, F., Jouzel, J., and Stocker, T. F.: Direct north-south synchronization of abrupt climate change record in ice cores using Beryllium 10, Clim. Past, 3, 541-547, doi:10.5194/cp-3-541-2007, 2007.

Raynaud, D., Lipenkov, V., Lemieux-Dudon, B., Duval, P., Loutre, M.-F., and Lhomme, N.: The local insolation signature of air content in Antarctic ice. A new step toward an absolute dating of ice records, Earth Planet. Sc. Lett., 261, 337-349, 2007.

Reeh, N.: Dating by ice flow modeling : a useful tool or an exercice in applied mathematics?, in:The environmental record in glaciers and ice sheets, edited by: Oeschger, H. C. and Langway, John Wiley \& Sons, New York, 1989.

Ritz, C., Rommelaere, V., and Dumas, C.: Modeling the evolution of Antarctic ice sheet over the last 420,000 years: implications for altitude changes in the Vostok region, J. Geophys. Res., 106, 31943-31964, 2001.

Röthlisberger, R., Mudelsee, M., Bigler, M., de Angelis, M., Fischer, H., Hansson, M., Lambert, F., Masson-Delmotte, V., Sime, L., Udisti, R., and Wolff, E. W.: The Southern Hemisphere at glacial terminations: insights from the Dome $\mathrm{C}$ ice core, Clim. Past, 4, 345-356, doi:10.5194/cp-4-345-2008, 2008.

Ruddiman, W. F. and McIntyre, A.: The mode and mechanism of the last deglaciation: Oceanic evidence, Quaternary Res., 16, 125134, 1981.

Ruth, U., Barnola, J.-M., Beer, J., Bigler, M., Blunier, T., Castellano, E., Fischer, H., Fundel, F., Huybrechts, P., Kaufmann, P., Kipfstuhl, S., Lambrecht, A., Morganti, A., Oerter, H., Parrenin, F., Rybak, O., Severi, M., Udisti, R., Wilhelms, F., and Wolff, E.: "EDML1": a chronology for the EPICA deep ice core from Dronning Maud Land, Antarctica, over the last 150000 years, Clim. Past, 3, 475-484, doi:10.5194/cp-3-475-2007, 2007.

Salamatin, A. N., Tsyganova, E. A., Popov, S. V., and Lipenkov, V. Y.: Ice flow line modeling in ice core data interpretation: Vostok Station (East Antarctica), in: Physics of Ice Core Records 2, edited by: Hondoh, T., Hokkaido University Press, Sapporo, 2009a.

Salamatin, A. N., Lipenkov, V. Y., Barnola, J. M., Hori, A., Duval, P., and Hondoh, T.: Snow-firn densification in polar ice sheets, in: Physics of Ice Core Records-2, edited by: Hondoh, T., Hokkaido University Press, Sapporo, 2009b.

Schilt, A., Baumgartner, M., Schwander, J., Buiron, D., Capron, E., Chappellaz, J., Loulergue, L., Schüpbach, S., Spahni, R., Fischer, H., and Stocker, T. F.: Atmospheric nitrous oxide during the last 140,000 years, Earth Planet. Sc. Lett., 300, 33-43, 2010.

Schwander, J. and Stauffer, B.: Age difference between polar ice and the air trapped in its bubbles, Nature, 311, 45-47, 1984.

Severi, M., Becagli, S., Castellano, E., Morganti, A., Traversi, R., Udisti, R., Ruth, U., Fischer, H., Huybrechts, P., Wolff, E., Parrenin, F., Kaufmann, P., Lambert, F., and Steffensen, J. P.: Synchronisation of the EDML and EDC ice cores for the last 
$52 \mathrm{kyr}$ by volcanic signature matching, Clim. Past, 3, 367-374, doi:10.5194/cp-3-367-2007, 2007.

Severi, M., Udisti, R., Becagli, S., Stenni, B., and Traversi, R.: Volcanic synchronisation of the EPICA-DC and TALDICE ice cores for the last $42 \mathrm{kyr} \mathrm{BP}$, Clim. Past, 8, 509-517, doi:10.5194/cp-8509-2012, 2012.

Severinghaus, J. P., Albert, M. R., Courville, Z. R., Fahnestock, M. A., Kawamura, K., Montzka, S. A., Mühle, J., Scambos, T. A., Shields, E., Shuman, C. A., Suwa, M., Tans, P., and Weiss, R. F.: Deep air convection in the firn at a zero-accumulation site, central Antarctica, Earth Planet. Sc. Lett., 293, 359-367, 2010.

Sime, L. C., Wolff, E. W., Oliver, K. I. C., and Tindall, J. C.: Evidence for warmer interglacials in East Antarctic ice cores, Nature, 462, 342-345, 2009.

Sowers, T., Bender, M., and Raynaud, D.: Elemental and isotopic composition of occluded $\mathrm{O}_{2}$ and $\mathrm{N}_{2}$ in polar ice, J. Geophys. Res., 94, 5137-5150, 1989.

Sowers, T. A., Bender, M., Raynaud, D., and Korotkevich, Y. L.: The $\delta^{15} \mathrm{~N}$ of $\mathrm{N}_{2}$ in air trapped in polar ice: a tracer of gas transport in the firn and a possible constraint on ice age-gas age differences, J. Geophys. Res., 97, 15683-15697, 1992.
Stenni, B., Buiron, D., Frezzotti, M., Albani, S., Barbante, C., Bard, E., Barnola, J. M., Baroni, M., Baumgartner, M., Bonazza, M., Capron, E., Castellano, E., Chappellaz, J., Delmonte, B., Falourd, S., Genoni, L., Iacumin, P., Jouzel, J., Kipfstuhl, S., Landais, A., Lemieux-Dudon, B., Maggi, V., Masson-Delmotte, V., Mazzola, C., Minster, B., Montagnat, M., Mulvaney, R., Narcisi, B., Oerter, H., Parrenin, F., Petit, J. R., Ritz, C., Scarchilli, C., Schilt, A., Schupbach, S., Schwander, J., Selmo, E., Severi, M., Stocker, T. F., and Udisti, R.: Expression of the bipolar see-saw in Antarctic climate records during the last deglaciation, Nat. Geosci., 4, 46-49, 2011.

Stocker, T. F. and Johnsen, S. J.: A minimum thermodynamic model for the bipolar seesaw, Paleoceanography, 18, 1-9, 2003.

Stommel, H.: Thermohaline convection with two stable regimes of flow, Tellus, 13, 224-230, 1961.

Witrant, E., Martinerie, P., Hogan, C., Laube, J. C., Kawamura, K., Capron, E., Montzka, S. A., Dlugokencky, E. J., Etheridge, D., Blunier, T., and Sturges, W. T.: A new multi-gas constrained model of trace gas non-homogeneous transport in firn: evaluation and behavior at eleven polar sites, Atmos. Chem. Phys. Discuss., 11, 23029-23080, doi:10.5194/acpd-11-23029-2011, 2011. 